Sains Malaysiana 50(11)(2021): 3421-3438

http://doi.org/10.17576/jsm-2021-5011-25

\title{
Efficiency of Higher Education in the Presence of Shared Inputs using Data Envelopment Analysis
}

(Kecekapan Pendidikan Tinggi dengan Perkongsian Input menggunakan Analisis Penyampulan Data)

\author{
Michael Gidey Gebru*, Saqlain Raza \& Mansoor Shaukat Khan
}

\section{ABSTRACT}

This study measures the efficiency of higher education institutions with respect to teaching activity, research activity, and overall activities and also provides a direction for low-performing institutions to improve their performance. In many instances, the efficiency of the institution is a sum up of the efficiency of its activities. However, when the activities consume some resources in common, it requires the allocation of shared resources among the activities. Since sums up the efficiency of each activity does not give the institution's overall efficiency, we use a joint data envelopment analysis that takes into account the institution's internal operations to measure the teaching efficiency, research efficiency, and overall efficiency of the institutions. The empirical results indicate that the institutions that execute both activities simultaneously become more productive rather than adopt a single activity. Hence, this study suggests a useful and measurable action to improve the institution's performance.

Keywords: Data envelopment analysis; efficiency; higher educations; shared inputs

\section{ABSTRAK}

Kajian ini mengukur kecekapan institusi pengajian tinggi dengan melihat kepada aktiviti pengajaran, aktiviti penyelidikan dan keseluruhan aktiviti serta memberikan panduan kepada institusi berprestasi rendah untuk meningkatkan prestasi mereka. Dalam banyak keadaan, kecekapan institusi diukur dengan jumlah kecekapan aktivitinya. Walau bagaimanapun, apabila aktiviti ini menggunakan beberapa sumber yang sama, ia memerlukan peruntukan pengagihan sumber antara aktiviti tersebut. Oleh kerana jumlah kecekapan setiap aktiviti tidak memberikan kecekapan keseluruhan institusi, kami menggunakan analisis penyampulan data yang mempertimbangkan operasi dalaman institusi untuk mengukur kecekapan pengajaran, kecekapan penyelidikan serta kecekapan keseluruhan institusi. Hasil empirik menunjukkan bahawa institusi yang menjalankan kedua-dua aktiviti tersebut secara serentak menjadi lebih produktif daripada yang menjalankan satu aktiviti. Maka, kajian ini mencadangkan tindakan yang berguna dan dapat diukur untuk meningkatkan prestasi institusi.

Kata kunci: Analisis penyampulan data; input dikongsi; kecekapan; pengajian tinggi

\section{INTRODUCTION}

According to Hanushek and Ludger (2008), the role of human capital in fostering social stability and economic development leads to emphasis on education in developing and low-income countries. The rationale of the policy is that developing human capital skills in the medium long term will help to improve the capacity of these countries to grow sustainably and rapidly. Investing more budget in education is not only sufficient to successfully achieve the goal of Higher Education Institutions (HEIs) but also to use their resources in efficient and effective ways, i.e. each money spent yields the highest possible level on the students' achievement. In the educational process, the role of institutions as an organization is important. In fact, the transmission of knowledge at institutions is the core of achievement that operates in an organized manner (Leithwood \& Menzies 1998).

Due to their innovation and transmission of knowledge, HEIs play a major role in development and are actively involved in implementing these in society (Boulton \& Lucas 2011). Vivid changes in the economy, technology, and culture are the result of the role of HEIs in the community. Teaching and research activities are 
connected to technology transfer, innovation, business incubators and private sector collaborations that boost regional growth activities (Fromhold-Eisebith \& Werker 2013). Public sector accomplishes its goals by successfully performing certain tasks and relying on its resources (Elbanna \& Abdel-Maksoud 2020).

A higher income and higher rate of employability with a university degree are directly related to the rank of HEIs (Moncayo-Martínez et al. 2020), and the growth of a country's economy depends on the success of higher education. Consequently, the performance of higher education needs to be evaluated. However, in developing and low-income countries, HEIs face many difficulties that affect their goals and operations, including low tuition, low investment in science and technology, increased matriculation, high spending, and low budget rather than developed world institutions. Thus, the institutions' policies are implemented on the basis of their country's needs and incentives.

Traditionally, many approaches have been used to evaluate organizational efficiency based on the concepts of Econometrics and Statistics. However, as suggested by Charnes et al. (1978), Data Envelopment Analysis (DEA) is the best technique for assessing the efficiency of public sector organizations. In addition, the DEA approach is the dominant approach to assessing the efficacy of healthcare, education and other sectors (Lall \& Teyarachakul 2006).

Many studies have been assessing the efficiency of the HEIs using the DEA approach. To the best of our knowledge, these studies used the conventional DEA model to estimate the institutions' efficiency by considering the institution as a 'Black box' and ignore the internal structure of the institution. However, HEI consists of teaching and research activities. These activities are interrelated and consume some resources in common so that sums up the efficiency of each activity does not provide the institution's overall efficiency. Hence, the conventional DEA model is not suitable for estimating HEI efficiency because this model does not take into account the institution's internal structure. For instance, Castano et al. (2007), Chen and Chen (2011), Kong and Fu (2012), Nazarko and Šaparauskas (2014), Sagarra et al. (2017), Shimshak and Wagner (2012), and Zhou and Wang (2009) are some of the studies that used the conventional DEA model. Moreover, Beasley (1995) used a DEA model to estimate the efficiency of universities with the parallel production system of teaching and research having a shared variable but the model is non-linear. To overcome these limitations, the authors developed a linear joint DEA model that takes into account the HEI's internal structure to estimate the institution's overall (joint) efficiency. Moreover, we have used a bootstrap approach that gives accurate and statistically significant results and is known as 'bias-free' (Simar \& Wilson 2007, 1998).

Another contribution of this study is to emphasize on the efficiency of HEIs in developing countries like Pakistan. Even though efficiency studies have been conducted in many countries particularly developed countries like United Kingdom, United States of America, Canada, Australia, and other European countries since the 1990s, the literature on the efficiency of higher educations in low-income and developing countries is very small. Some of the studies conducted in developing countries (Taylor \& Harris 2004) measured ten South African universities performance and the empirical finding showed that their efficiency was found in the range of 0.86 and 0.914; Castano and Cabanda (2007) estimated the efficiency of thirty Philippines' private HEIs and majority of the institutions were inefficient based on the finding, and Zoghbi et al. (2013) measured the efficiency of one hundred sixty-four Brazil universities and their efficiency scores found in the range from 0.350 to 0.406 .

The paper is organized as follows: Next section provides a literature review on the DEA approach and the efficiency of higher educations. Explanations of the selected variables for the data are provided in the subsequent section. The methods used to assess teaching efficiency, research efficiency, and overall efficiency is discussed in the following section. The result is analyzed subsequently. Lastly, conclusions are provided.

\section{REVIEW LITERATURE}

From the literature of the educational efficiency measure using DEA approach, two major streams have been identified: First, its objective was to assess the efficiency of basic educations. For instance, the efficiency of secondary schools in Finland (Kirjavainen \& Loikkanent 1998), England (Bradley et al. 2001; Mancebon \& Molinero 2000), and Latin America (Dufrechou 2016). Second, its objective was to assess the efficiency of higher educations in the United States of America, China, Malaysia, United Kingdom, Israel, Australia, Greece, Canada, Taiwan, Poland, and Finland (Liu et al. 2013; Nazarko \& Šaparauskas 2014; Shimshak \& Wagner 2012). Due to some characteristics of the HEIs, it is difficult to measure their efficiency. In addition, it can be difficult 
to determine the exact input levels needed in order to achieve the desired results. Therefore, the complexity of the institution and subjectivity of the educational results, selection of appropriate performance indicators is extremely difficult (Johnes 2006). However, in the manufacturing and financial business context, it is often possible to develop a single summary measure of performance, such as profit, sales, income, or market share.

HEIs play a major role in a country's economic growth by producing highly qualified human power and new knowledge (Johnes 2006). The education sector that receives huge amounts of government budget increases the accountability in the use of its resources efficiently. Moreover, Due to the lack of budget allocation from the Higher Education Commission (HEC) to the HEIs, the institutions are obliged to begin work on alternative approaches in order to achieve greater efficiency and generate capital resources. This combination of resourcegenerating motivation and complex HEI goals makes it difficult to measure HEIs' efficiency (Herbst 2007).

Previous studies have shown that higher education can achieve higher levels of performance relative to the amount invested in it, rather than the correlation between education expenditure and the results obtained (Afonso \& Aubyn 2006; Agasisti 2014). According to Gupta et al. (2002), the existence of disparate efficiency levels in education sector has been measured due to low investment in it. Hence, high investment in the educational system correlated with better academic performance.

The advantage in evaluating the efficiency of HEIs using a non-parametric technique is to include multiple inputs and multiple outputs without any prior information and require only the quantities of inputs and outputs. This makes the analysis suitable, even if it is difficult to the observed price of inputs and outputs. Moreover, it helps to identify efficient and inefficient institutions and gives direction on how the inefficient institutions can be efficient (Johnes \& Li 2008). However, Stochastic Frontier Analysis estimates the efficiency of the institutions with a specification bias since it requires to define a priori functional form of the production frontier (Simar \& Wilson 2007).

Some of the studies that used the DEA approach to measure the efficiency of HEIs are the efficiency of Mexican universities using integrating DEA and multidimensional scaling (Sagarra et al. 2017); the efficiency research activity of Australian HEIs using NDEA and DEA approach (Lee \& Worthington 2016); the performance of business colleges in Taiwan using AR-
DEA approach (Kong \& Fu 2012); the technical and scale efficiency of Australians governmental universities using DEA approach (Abbott \& Doucouliagos 2003); the InnoQual performance of 99 Taiwanese universities using DEA approach (Chen \& Chen 2011) and the technical efficiency of public Tunisian universities on research and teaching activities using DEA approach (Ramzi \& Ayadi 2016).

\section{DATA}

This section presents the variables used to measure teaching efficiency, research efficiency, and overall efficiency of HEIs. In order to analysis the non-parametric approach, the key important step is to identify suitable data variables and the model relies on selected variables. Even if the selection of variables in the higher education system is not clearly defined, it is necessary to select the appropriate variables to quantify the precise efficiency of the institutions.

It is difficult to use market-oriented outputs like profit and economic value of inputs to measure the efficiency of a HEI (Hanushek \& Luque 2003). No precise definition is stated and real measurements are difficult to define in the selection of inputs and outputs. Moreover, most studies have shown inconsistency in evaluating higher education efficiency and faced difficulty in evaluating the interaction between the various variables. For instance, improvement of the efficiency of HEIs correlated with generating of additional revenue (Joumady \& Ris 2005); various types and impacts of resource allocation on the performance of HEI (Liefner 2003) and higher education performance measures were divided into four indicators: Input, process, output and outcome (Lang \& Zha 2004). Therefore, a common way of choosing suitable inputs and outputs for the DEA model is to align the assessment goal and the chosen variables must have a positive relationship among themselves.

For this study, data has been collected from the annual reports of Pakistani HEIs for the period of 2017-2018. The report has included interrelated survey components. Of those survey, the following has been used: (a) human resources survey with details about academic and general duty staff; (b) an enrollment survey for undergraduate and graduate levels; (c) a survey of completions which indicates a degree of completion by level and performance of the graduated; (d) a survey of capital resources which details about research grants; and (e) an instructional characteristics survey which provides detailed information about laboratories and libraries. From this report, six inputs and four outputs are 
used to measure teaching efficiency, research efficiency, and overall efficiency of HEIs.

Inputs for teaching activity are the number of hours per day with respect to the total number of faculty members carrying out teaching activity $\left(\mathrm{x}_{1}\right)$, the number of hours per day with respect to teaching activity perform in all laboratories $\left(\mathrm{x}_{2}\right)$, the number of libraries $\left(\mathrm{x}_{3}\right)$, and the number of enrolled courses taught to students $\left(\mathrm{x}_{4}\right)$ while outputs are the number of graduated students from courses taught $\left(\mathrm{y}_{1}\right)$, average graduates' result or CGPA $\left(\mathrm{y}_{2}\right)$ and the number of graduates' rate $\left(\mathrm{y}_{3}\right)$. Similarly, inputs for research activity are the number of hours per day with respect to the total number of faculty members carrying out research activities $\left(\mathrm{x}_{1}\right)$, the number of hours per day with respect to research activity perform in all laboratories $\left(\mathrm{x}_{2}\right)$, the number of $\mathrm{PhD}$ thesis supervised $\left(\mathrm{x}_{5}\right)$ and amount of research grant in millions $\left(\mathrm{x}_{6}\right)$ while the output is the number of published research papers, books, and conferences $\left(\mathrm{y}_{4}\right)$. Figure 1 illustrates the composite of six inputs and four outputs to estimate the teaching efficiency, the research efficiency, and the overall efficiency of HEIs during the given time interval.

The data was collected from public and private HEIs which are located in every province of the country. High variability among the institutions was found. For instance, some institutions have a smaller number of faculty members and a higher number of enrolled students. On the contrary, institutions with a high number of faculty members and students' enrolment like 'The Punjab University'. Institutions in which a large proportion of their students are people of low and medium socioeconomic status while institutions with a large proportion of their students from people of high socioeconomic status. Institutions with better infrastructure while others with low infrastructure.

From these listed inputs, we observed that faculty members and laboratory are consumed by both activities and taken as shared resources. On average, teaching and research activities at HEIs are performed in the laboratory for 8 hours per day. To measure the
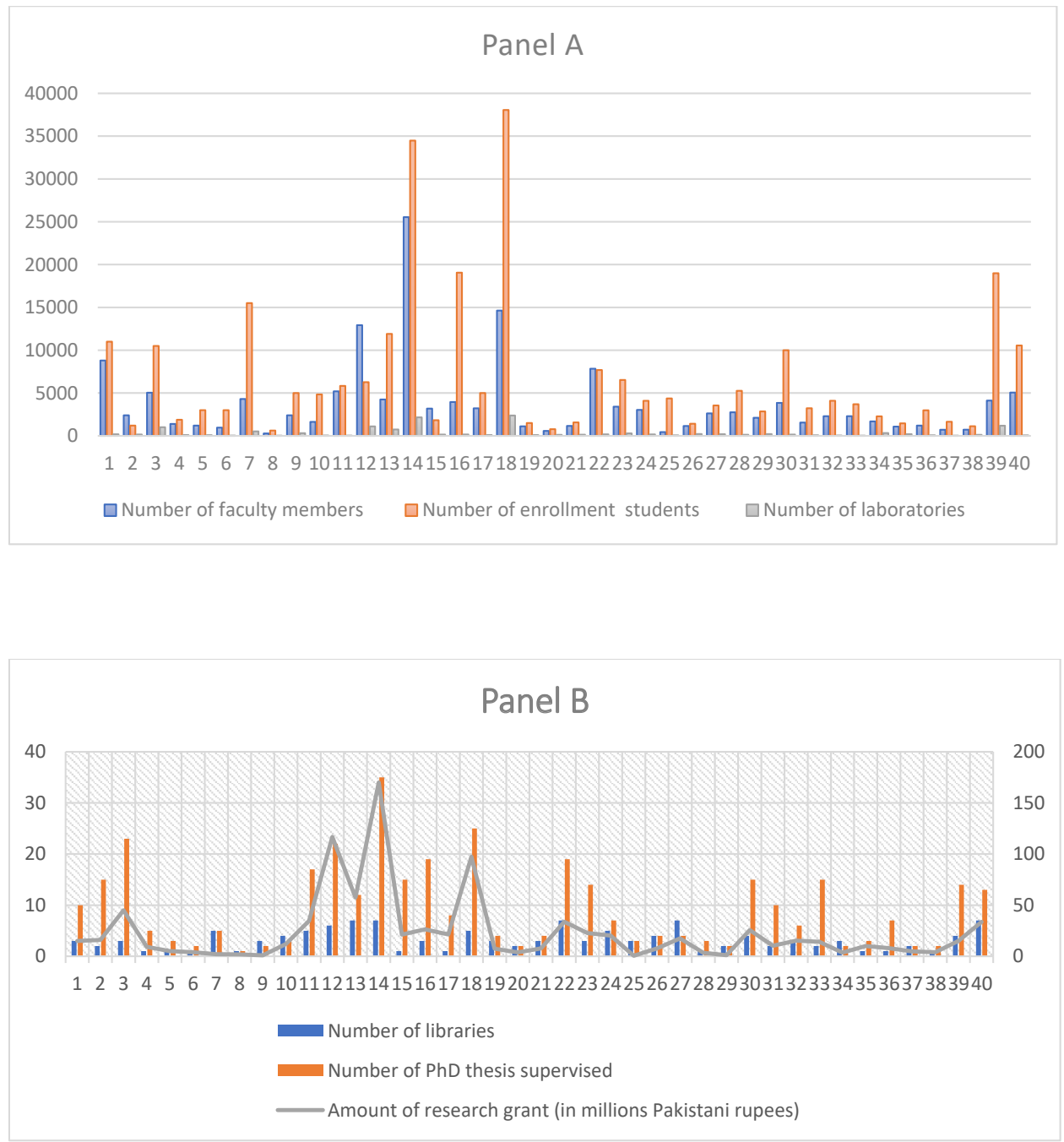

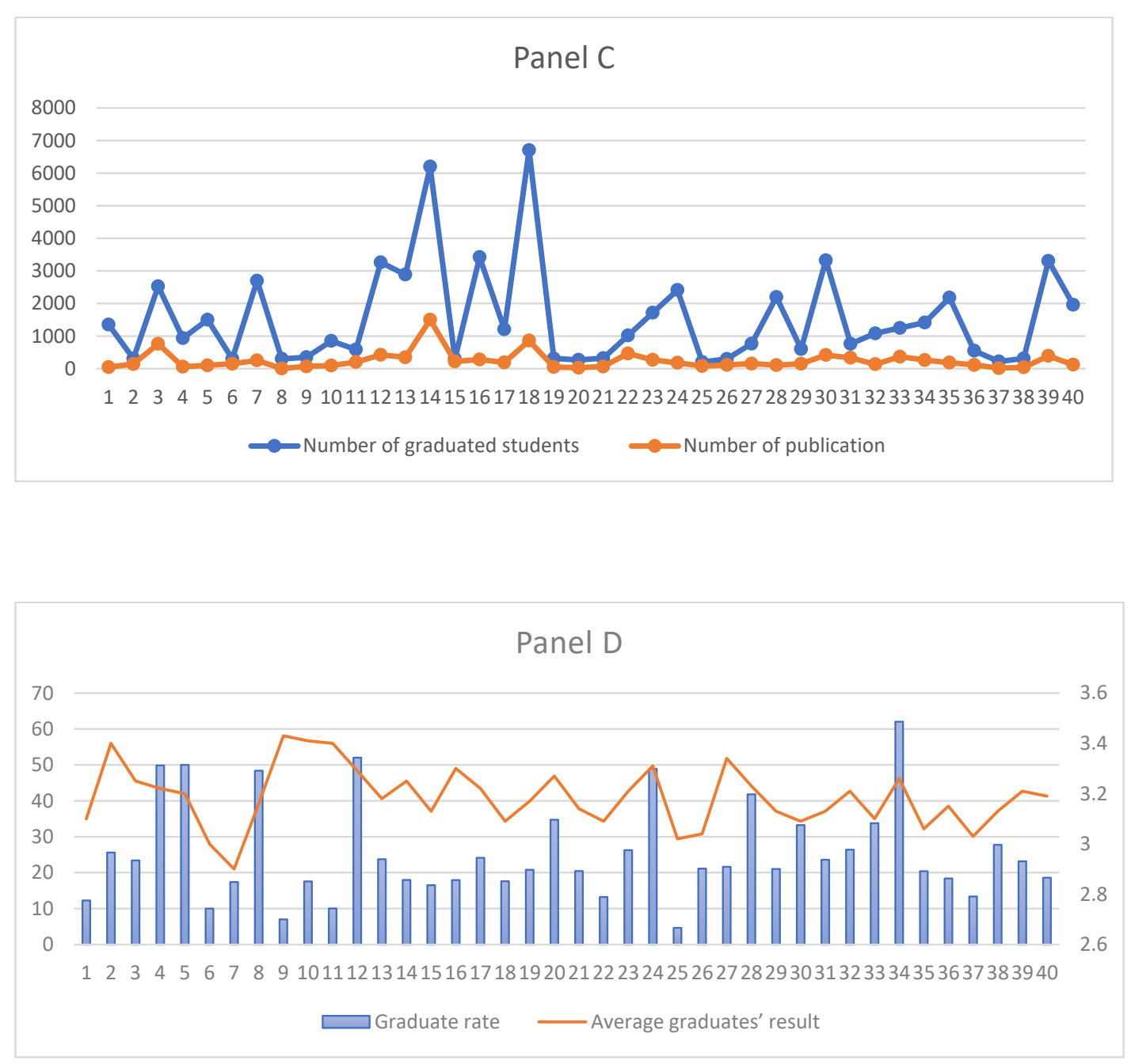

Data has taken from HEC

FIGURE 1. Data of 40 HEIs for the period of 2017-2018

efficiency of each activity, we need to allocate the given specific time interval to each activity because the activities may or may not have equal weight in performing their activities in the laboratory. Similarly, we also need to allocate the given specific time interval in which faculty members are involved in teaching and research activities to measure the efficiency of each activity of the institution.

Clearly, HEI performs teaching and research activities simultaneously, thus, disaggregate shared resources is very important for measuring the efficiency of each activity because teaching and research consume some shared inputs and sum up the efficiency of each activity does not give the overall efficiency of the institution.

\section{METHODS}

This section explains the model used to measure teaching efficiency, research efficiency, and overall efficiency of HEIs. Hence, we carry out two stages: in the first step, measuring teaching efficiency, research efficiency, and overall efficiency of HEIs using the DEA approach, and in the second step, eliminating the sensitivity of efficiency scores using the bootstrap technique. 


\section{DATA ENVELOPMENT ANALYSIS}

DEA model is a non-parametric mathematical programming approach used to measure the relative efficiency of Decision-Making Units (DMUs) involving multiple inputs and multiple outputs. The DEA model was first introduced by Farrell (1957) using only single input and single output. Later, Charnes et al. (1978) developed the model using multiple inputs and multiple outputs and proposed it as CCR model that operates under the assumption of Constant Returns to Scale (CRS). Similarly, Banker et al. (1984) revised the CCR model and developed a BCC model that operates under the assumption of Variable Returns to Scale (VRS).

The DEA model can also be classified into input orientation and output orientation. In the input orientation model, it describes the frontier by keeping output levels as constant to minimize input consumption to optimize level. For the output orientation model, it describes the frontier by keeping the input level as constant to maximize possible output production. Hence, the researcher should align the model's selection of orientation with the expected results. In his work, Sacoto (2012) used the output orientation model to measure business school efficiency and tried to optimize internships and employment by no longer using scholarships and grants from academic schools. In the context of education, the goal is to maximize output production. Therefore, the output-oriented model is the appropriate orientation for this study (Cook et al. 2014).

Assume that there are ' $n$ ' DMUs where each $D M U_{j}$ has two sub-units that are carried out activities simultaneously. The production system consists of subunit one one $\left(S U^{1}\right)$ and sub-unit two $\left(S U^{2}\right)$ Every $D M U_{j}$ $(j=1,2, \ldots, n)$ employs ' $m$ ' inputs $x_{i j}(i=1,2, \ldots \mathrm{r}, \ldots, m)$ and produces two types of outputs: $S U_{1}$ outputs $y_{h j}(h=$ $1,2 \ldots, q)$ and $S U_{2}$ outputs $y_{h j}(h=q+1, q+2, \ldots, s)$. We also assume that $D M U_{j}$ has 'r' inputs $x_{i j}(i=1,2, \ldots$ $r$ ) which are shared for both sub-units. Some portion $\mu_{i}$ of the shared inputs $x_{i j}(i=1,2, \ldots r)$ allocated to $\left(S U^{1}\right)$ and the remained $1-\mu_{i}$ is allocated to $\left(S U^{2}\right)$ with $0<\mu_{i}<$ 1. Suppose that the input weights $u_{i}(i=1,2, \ldots, m)$ and output weights $v_{h}(h=1,2, \ldots, s)$ are variables.

Inputs and outputs associated with $\left(S U^{1}\right)$ and $\left(S U^{2}\right)$ are denoted by the superscript's 'T' and 'R', respectively. Shared inputs associated with $\left(S U^{1}\right)$ and $\left(S U^{2}\right)$ are denoted by the superscript 'S'. Similarly, weights associated with shared inputs of $\left(S U^{1}\right)$ and shared inputs of $\left(S U^{2}\right)$ are denoted by the superscript 'TS' and 'RS', respectively.
Based on the existence of two subunits $S U^{1}$ and $S U^{2}$, the model is derived for the units that consume some subunit specific inputs and some shared inputs to produce some subunit specific outputs. For $D M U_{k}$, we have the following ' $r$ ' shared inputs $: x_{1}^{s}, x_{2}^{s}, \ldots, x_{r}^{s}$. These shared inputs consume by $S U^{1}$ of $D M U_{k}$ and $S U^{2}$ of $D M U_{k}$. Formally, we have,

Shared inputs consumed by $S U^{1}$ of $D M U_{k}: \mu_{1} x_{1}^{s}, \mu_{2}$ $x_{2}^{s}, \ldots, \mu_{r} x_{r}^{s}$

and

Shared inputs consumed by $S U^{2}$ of $D M U_{k}:\left(1-\mu_{1}\right) x_{1}^{s}$, $\left(1-\mu_{2}\right) x_{2} s, \ldots,\left(1-\mu_{r}\right) x_{r}^{s}$ where $0<\mu_{i}<1, i=1,2, \ldots, \mathrm{r}$.

Two efficiency indexes for specific $D M U_{k}$ are defined: efficiency of $S U^{1}$ or $\left(e_{k}^{1}\right)$ and efficiency of $S U^{2}$ or $\left(e_{k}^{2}\right)$. Using Banker et al. (1984), the outputs $y_{j h}(h=$ $1,2, \ldots, s)$ are produced from the inputs $x_{i j}(i=1,2$, $\ldots \mathrm{r}, \ldots, m)$. Hence, the efficiency of $S U^{1}$ or $\left(e_{k}^{1}\right)$ and the efficiency of $S U^{2}$ or $\left(e_{k}^{2}\right)$ are defined as

$$
\begin{aligned}
e_{k}^{1} & =\frac{\sum_{\mathrm{h}=1}^{\mathrm{q}} \mathrm{v}_{\mathrm{h}}^{\mathrm{T}} \mathrm{y}_{\mathrm{hk}}^{\mathrm{T}}}{\sum_{\mathrm{i}=1}^{\mathrm{r}} \mathrm{u}_{\mathrm{i}}^{\mathrm{TS}}\left(\mu_{\mathrm{i}} \mathrm{x}_{\mathrm{ik}}^{\mathrm{S}}\right)+\sum_{\mathrm{i}=\mathrm{r}+1}^{\mathrm{w}} \mathrm{u}_{\mathrm{i}}^{\mathrm{T}} \mathrm{x}_{\mathrm{ik}}^{\mathrm{T}}} \\
e_{k}^{2} & =\frac{\sum_{\mathrm{h}=1+\mathrm{q}}^{\mathrm{S}} \mathrm{v}_{\mathrm{h}}^{\mathrm{R}} \mathrm{y}_{\mathrm{hk}}^{\mathrm{R}}}{\sum_{\mathrm{i}=1}^{\mathrm{r}} \mathrm{u}_{\mathrm{i}}^{\mathrm{RS}}\left(1-\mu_{i}\right) x_{i k}^{\mathrm{S}}+\sum_{\mathrm{i}=\mathrm{w}+1}^{\mathrm{m}} \mathrm{u}_{\mathrm{i}}^{\mathrm{R}} \mathrm{x}_{\mathrm{ik}}^{\mathrm{R}}}
\end{aligned}
$$

\section{STATEMENT OF A PROBLEM}

Suppose that $D M U_{j}$ consist of two sub-units that carried out activities simultaneously. Obtain the optimum variables $u_{i}$ and $v_{h}$ to optimize the overall efficiency of the $D M U_{j}$.

\section{DERIVATION OF JOINT EFFICIENCY OF $S U^{1}$ AND $S U^{2}$}

Measurements of $\left(e_{j}^{1}\right)$ and $\left(e_{j}^{2}\right)$ depends on the variables $u_{i}$ and $v_{h}$. Using a DEA technique, $u_{i}$ and $v_{h}$ can be determined to maximize the overall efficiency $e_{j}$ of the joint production process of $D M U_{i}$. Using the concept of goal programming, the objective function of the overall efficiency of $D M U_{k}$ is defined as

$$
e_{k}=\lambda_{\mathrm{k}} e_{k}^{1}+\left(1-\lambda_{\mathrm{k}}\right) e_{k}^{2}
$$

where $\lambda_{\mathrm{k}}$ is the weight of $e_{k}^{1}$, and $\left(1-\lambda_{\mathrm{k}}\right)$ is the weight of $e_{k}^{2}$ for the $D M U_{k}$.

According to Molinero (1996), $e_{k}{ }^{1}$ is the relative efficiency of the $S U^{1}$ for the $\mathrm{k}^{\text {th }}$ DMU while is the relative 
efficiency of the $S U^{2}$ for the $\mathrm{k}^{\text {th }}$ DMU. Even if it is not necessary, $\lambda_{\mathrm{k}}$ and $1-\lambda_{\mathrm{k}}$ can be normalized so that they can be added to one. $e_{k}$ can be taken as a measure of the overall efficiency of the having subunits in it when this is done. Hence, the joint output maximizing model comprising of inequalities 1-2 and the objective function (3) and the model can be defined as follow:

$$
\begin{gathered}
\max e_{k}=\lambda_{\mathrm{k}} e_{k}^{1}+\left(1-\lambda_{\mathrm{k}}\right) e_{k}^{2} \\
\text { Subject to } \quad \sum_{\mathrm{h}=1}^{\mathrm{q}} \mathrm{v}_{\mathrm{h}}^{\mathrm{T}} y_{\mathrm{hj}}^{\mathrm{T}}-\sum_{\mathrm{i}=1}^{\mathrm{r}} \mathrm{u}_{\mathrm{i}}^{\mathrm{TS}}\left(\mu_{i} \mathrm{x}_{\mathrm{ij}}^{\mathrm{S}}\right)+\sum_{\mathrm{i}=\mathrm{r}+1}^{\mathrm{w}} \mathrm{u}_{\mathrm{i}}^{\mathrm{T}} \mathrm{x}_{\mathrm{ij}}^{\mathrm{T}} \leq 0, \forall j \\
\sum_{\mathrm{h}=1+\mathrm{q}}^{\mathrm{s}} \mathrm{v}_{\mathrm{h}}^{\mathrm{R}} \mathrm{y}_{\mathrm{hj}}^{\mathrm{R}}-\sum_{\mathrm{i}=1}^{\mathrm{r}} \mathrm{u}_{\mathrm{i}}^{\mathrm{RS}}\left(1-\mu_{i}\right) x_{i j}^{S}+\sum_{\mathrm{i}=\mathrm{w}+1}^{\mathrm{m}} \mathrm{u}_{\mathrm{i}}^{\mathrm{R}} \mathrm{x}_{\mathrm{ij}}^{\mathrm{R}} \leq 0, \forall j \\
\mathrm{v}_{\mathrm{h}} \geq \varepsilon, \forall h \\
\mathrm{u}_{\mathrm{i}} \geq \varepsilon, \forall i
\end{gathered}
$$

Since $u_{i}$ and $v_{h}$ are decision variables, model (4) is nonlinear fractional program. Model (4) transforms to linear fractional program as follow:

$$
\begin{gathered}
\operatorname{maxe}_{k}=\lambda_{\mathrm{k}} \frac{\sum_{\mathrm{h}=1}^{\mathrm{q}} \mathrm{v}_{\mathrm{h}}^{\mathrm{T}} y_{h \mathrm{~h}}^{\mathrm{T}}}{\sum_{\mathrm{i}=1}^{\mathrm{r}} \mathrm{u}_{\mathrm{i}}^{\mathrm{TS}}\left(\mu_{i} \mathrm{x}_{\mathrm{ik}}^{\mathrm{S}}\right)+\sum_{\mathrm{i}=\mathrm{r}+1}^{\mathrm{W}} \mathrm{u}_{\mathrm{i}}^{\mathrm{T}} \mathrm{x}_{\mathrm{ik}}^{\mathrm{T}}}+\left(1-\lambda_{\mathrm{k}}\right) \frac{\sum_{\mathrm{h}=1+\mathrm{q}}^{\mathrm{S}} \mathrm{v}_{\mathrm{h}}^{\mathrm{R}} y_{\mathrm{hk}}^{\mathrm{R}}}{\sum_{\mathrm{i}=1}^{\mathrm{r}} \mathrm{u}_{\mathrm{i}}^{\mathrm{RS}}\left(1-\mu_{i}\right) x_{i k}^{\mathrm{S}}+\sum_{\mathrm{i}=\mathrm{w}+1}^{\mathrm{m}} \mathrm{u}_{\mathrm{i}}^{\mathrm{R}} \mathrm{x}_{\mathrm{ik}}^{\mathrm{R}}} \\
\text { Subject to } \quad \sum_{\mathrm{h}=1}^{\mathrm{q}} \mathrm{v}_{\mathrm{h}}^{\mathrm{T}} \mathrm{y}_{\mathrm{hj}}^{\mathrm{T}}-\sum_{\mathrm{i}=1}^{\mathrm{r}} \mathrm{u}_{\mathrm{i}}^{\mathrm{TS}}\left(\mu_{i} \mathrm{x}_{\mathrm{ij}}^{\mathrm{S}}\right)-\sum_{\mathrm{i}=\mathrm{r}+1}^{\mathrm{w}} \mathrm{u}_{\mathrm{i}}^{\mathrm{T}} \mathrm{x}_{\mathrm{ij}}^{\mathrm{T}} \leq 0, \forall j \\
\sum_{\mathrm{h}=1+\mathrm{q}}^{\mathrm{s}} \mathrm{v}_{\mathrm{h}}^{\mathrm{R}} \mathrm{y}_{\mathrm{hj}}^{\mathrm{R}}-\sum_{\mathrm{i}=1}^{\mathrm{r}} \mathrm{u}_{\mathrm{i}}^{\mathrm{RS}}\left(1-\mu_{i}\right) x_{i j}^{S}-\sum_{\mathrm{i}=\mathrm{r}+1}^{\mathrm{z}} \mathrm{u}_{\mathrm{i}}^{\mathrm{R}} \mathrm{x}_{\mathrm{ij}}^{\mathrm{R}} \leq 0, \forall j \\
\mathrm{v}_{\mathrm{h}} \geq \varepsilon, \forall h \\
\mathrm{u}_{\mathrm{i}} \geq \varepsilon, \forall i
\end{gathered}
$$

To transform model (5) into a linear program, we find out $\lambda_{\mathrm{k}}$ and $1-\lambda_{\mathrm{k}}$ which represent the weight of $e_{k}{ }^{1}$ and $e_{k}{ }^{2}$. Hence, since $S U^{1}$ is a partition of the whole process of the and from the goal programming concept, we define $\lambda_{k}$ as the ratio of virtual inputs of $S U^{1}$ to total virtual inputs of the $D M U_{k}$. Mathematically,

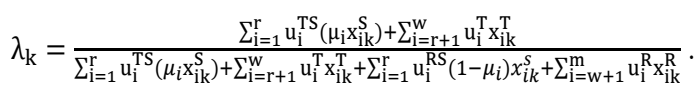

Similarly, since $S U^{2}$ is a partition of the whole process of the DMU and from the goal programming concept, we define $1-\lambda_{\mathrm{k}}$ as the ratio of virtual inputs of $S U^{2}$ to total virtual inputs of the DMUk. Mathematically,

$1-\lambda_{\mathrm{k}}=1-\frac{\sum_{\mathrm{i}=1}^{\mathrm{r}} \mathrm{u}_{\mathrm{i}}^{\mathrm{TS}}\left(\mu_{\mathrm{i}} \mathrm{x}_{\mathrm{ik}}^{\mathrm{S}}\right)+\sum_{\mathrm{i}=\mathrm{r}+1}^{\mathrm{w}} \mathrm{u}_{\mathrm{i}}^{\mathrm{T}} \mathrm{x}_{\mathrm{i}}^{\mathrm{T}}}{\sum_{\mathrm{i}=1}^{\mathrm{r}} \mathrm{u}_{\mathrm{i}}^{\mathrm{TS}}\left(\mu_{i} \mathrm{x}_{\mathrm{ik}}^{\mathrm{S}}\right)+\sum_{\mathrm{i}=\mathrm{r}+1}^{\mathrm{w}} \mathrm{u}_{\mathrm{i}}^{\mathrm{T}} \mathrm{x}_{\mathrm{ik}}^{\mathrm{T}}+\sum_{\mathrm{i}=1}^{\mathrm{r}} \mathrm{u}_{\mathrm{i}}^{\mathrm{RS}}\left(1-\mu_{i}\right) x_{i k}^{S}+\sum_{\mathrm{w}+1}^{\mathrm{m}} \mathrm{u}_{\mathrm{i}}^{\mathrm{R}} \mathrm{x}_{\mathrm{ik}}^{\mathrm{R}}}(7)$

Thus, the objective function of the model (5) becomes

$$
e_{k}=\lambda_{\mathrm{k}} e_{k}^{1}+\left(1-\lambda_{\mathrm{k}}\right) e_{k}^{2}
$$

Hence, the joint efficiency $\left(e_{k}\right)$ of $\mathrm{DMU}_{\mathrm{k}}$ is computed by using the following linear fractional form:

$$
\begin{aligned}
& \operatorname{maxe}_{k}=\frac{\sum_{\mathrm{h}=1}^{\mathrm{q}} \mathrm{v}_{\mathrm{h}}^{\mathrm{T}} \mathrm{y}_{\mathrm{hk}}^{\mathrm{T}}+\sum_{\mathrm{h}=1+\mathrm{q}}^{\mathrm{s}} \mathrm{v}_{\mathrm{h}}^{\mathrm{R}} \mathrm{y}_{\mathrm{hk}}^{\mathrm{R}}}{\sum_{\mathrm{i}=1}^{\mathrm{r}} \mathrm{u}_{\mathrm{i}}^{\mathrm{TS}}\left(\mu_{i} \mathrm{x}_{\mathrm{ik}}^{\mathrm{S}}\right)+\sum_{\mathrm{i}=\mathrm{r}+1}^{\mathrm{W}} \mathrm{u}_{\mathrm{i}}^{\mathrm{T}} \mathrm{x}_{\mathrm{ik}}^{\mathrm{T}}+\sum_{\mathrm{i}=1}^{\mathrm{r}} \mathrm{u}_{\mathrm{i}}^{\mathrm{RS}}\left(1-\mu_{i}\right) x_{i k}^{\mathrm{S}}+\sum_{\mathrm{i}=\mathrm{r}+1}^{\mathrm{z}} \mathrm{u}_{\mathrm{i}}^{\mathrm{R}} \mathrm{x}_{\mathrm{ik}}^{\mathrm{R}}} \\
& \text { Subject to } \sum_{\mathrm{h}=1}^{\mathrm{q}} \mathrm{v}_{\mathrm{h}}^{\mathrm{T}} \mathrm{y}_{\mathrm{hj}}^{\mathrm{T}}-\sum_{\mathrm{i}=1}^{\mathrm{r}} \mathrm{u}_{\mathrm{i}}^{\mathrm{TS}}\left(\mu_{i} \mathrm{x}_{\mathrm{ij}}^{\mathrm{S}}\right)-\sum_{\mathrm{i}=\mathrm{r}+1}^{\mathrm{w}} \mathrm{u}_{\mathrm{i}}^{\mathrm{T}} \mathrm{x}_{\mathrm{ij}}^{\mathrm{T}} \leq 0, \forall j \\
& \sum_{\mathrm{h}=1+\mathrm{q}}^{\mathrm{s}} \mathrm{v}_{\mathrm{h}}^{\mathrm{R}} \mathrm{y}_{\mathrm{hj}}^{\mathrm{R}}-\sum_{\mathrm{i}=1}^{\mathrm{r}} \mathrm{u}_{\mathrm{i}}^{\mathrm{RS}}\left(1-\mu_{i}\right) x_{i j}^{S}-\sum_{\mathrm{i}=\mathrm{r}+1}^{\mathrm{z}} \mathrm{u}_{\mathrm{i}}^{\mathrm{R}} \mathrm{x}_{\mathrm{ij}}^{\mathrm{R}} \leq 0, \forall j \\
& \mathrm{v}_{\mathrm{h}} \geq \varepsilon, \forall h \\
& \mathrm{u}_{\mathrm{i}} \geq \varepsilon, \forall i
\end{aligned}
$$

Since model (9) is in a linear fractional form, using the Charnes and Cooper (1962), the model can be converted into an analogous linear programming form:

$$
\operatorname{maxe}_{k}=\sum_{\mathrm{h}=1}^{\mathrm{q}} \mathrm{v}_{\mathrm{h}}^{\mathrm{T}} \mathrm{y}_{\mathrm{hk}}^{\mathrm{T}}+\sum_{\mathrm{h}=1+\mathrm{q}}^{\mathrm{s}} \mathrm{v}_{\mathrm{h}}^{\mathrm{R}} \mathrm{y}_{\mathrm{hk}}^{\mathrm{R}}
$$

Subject to $\sum_{\mathrm{i}=1}^{\mathrm{r}} \mathrm{u}_{\mathrm{i}}^{\mathrm{TS}}\left(\mu_{i} \mathrm{x}_{\mathrm{ik}}^{\mathrm{S}}\right)+\sum_{\mathrm{i}=\mathrm{r}+1}^{\mathrm{w}} \mathrm{u}_{\mathrm{i}}^{\mathrm{T}} \mathrm{x}_{\mathrm{ik}}^{\mathrm{T}}+\sum_{\mathrm{i}=1}^{\mathrm{r}} \mathrm{u}_{\mathrm{i}}^{\mathrm{RS}}\left(1-\mu_{i}\right) x_{i k}^{S}+$

$$
\begin{gathered}
\sum_{\mathrm{i}=\mathrm{r}+1}^{\mathrm{z}} \mathrm{u}_{\mathrm{i}}^{\mathrm{R}} \mathrm{x}_{\mathrm{ik}}^{\mathrm{R}}=1 \\
\sum_{\mathrm{h}=1}^{\mathrm{q}} \mathrm{v}_{\mathrm{h}}^{\mathrm{T}} \mathrm{y}_{\mathrm{hj}}^{\mathrm{T}}-\sum_{\mathrm{i}=1}^{\mathrm{r}} \mathrm{u}_{\mathrm{i}}^{\mathrm{TS}}\left(\mu_{i} \mathrm{x}_{\mathrm{ij}}^{\mathrm{S}}\right)-\sum_{\mathrm{i}=\mathrm{r}+1}^{\mathrm{w}} \mathrm{u}_{\mathrm{i}}^{\mathrm{T}} \mathrm{x}_{\mathrm{ij}}^{\mathrm{T}} \leq 0, \forall \\
\sum_{\mathrm{h}=1+\mathrm{q}}^{\mathrm{s}} \mathrm{v}_{\mathrm{h}}^{\mathrm{R}} \mathrm{y}_{\mathrm{hj}}^{\mathrm{R}}-\sum_{\mathrm{i}=1}^{\mathrm{r}} \mathrm{u}_{\mathrm{i}}^{\mathrm{RS}}\left(1-\mu_{i}\right) x_{i j}^{\mathrm{S}}-\sum_{\mathrm{i}=\mathrm{r}+1}^{\mathrm{z}} \mathrm{u}_{\mathrm{i}}^{\mathrm{R}} \mathrm{x}_{\mathrm{ij}}^{\mathrm{R}} \leq 0, \forall j \\
\mathrm{v}_{\mathrm{h}} \geq \varepsilon, \forall h \\
\mathrm{u}_{\mathrm{i}} \geq \varepsilon, \forall i
\end{gathered}
$$

It is clear that the optimal solutions for model (10) are optimal solutions for model (4). In model (10), the objective value is the overall efficiency of $\mathrm{DMU}_{\mathrm{k}}$. When we have an optimal solution to model (10), it implies that the model includes the components with shared resources in its computation of the overall efficiency of the $D M U_{k}$.

According to available data, there are 40 DMUs: $\mathrm{DMU}_{\mathrm{j}}(\mathrm{j}=1,2, \ldots, 40)$. Each $D M U_{j}(j=1,2, \ldots, 40)$ uses 6 inputs $x_{i j}(i=1,2, \ldots, 6)$ and produce ' 4 ' outputs $y_{j h}(h$ $=1,2 \ldots, 4)$. Let the input weight $u_{i}(i=1,2, \ldots, 6)$ and output weight $v_{j}(h=1,2 \ldots, 4)$ are variables. Let $D M U_{j}$ to be evaluated to design $D M U_{k}(k=1,2,3 \ldots 40)$.

While performing teaching and research, some inputs only involve teaching. On the other hand, some of the inputs are only involved in research. Besides, some of the inputs involved in both are known as 'shared inputs'. Let $u_{1}$ be the proportion of the number of hours per day carrying out teaching, then $1-\mu_{1}$ be the proportion of the number of hours per day carrying out the research.

$$
0<\mu_{1}<1
$$

In general,

$$
0<\mu_{i}<1
$$


Then, teaching efficiency $\left(T_{k}\right)$ of each $D M U_{k}$ can be evaluated using linear programming:

$$
\max \sum_{\mathrm{h}=1}^{3} \mathrm{v}_{\mathrm{h}}^{\mathrm{T}} \mathrm{y}_{\mathrm{hk}}^{\mathrm{T}}
$$

Subject to $\quad \sum_{\mathrm{i}=1}^{2} \mathrm{u}_{\mathrm{i}}^{\mathrm{TS}}\left(\mu_{\mathrm{i}} \mathrm{x}_{\mathrm{ik}}^{\mathrm{S}}\right)+\sum_{\mathrm{i}=3}^{4} \mathrm{u}_{\mathrm{i}}^{\mathrm{T}} \mathrm{x}_{\mathrm{ik}}^{\mathrm{T}}=1$

$$
\begin{gathered}
\sum_{\mathrm{r}=1}^{3} \mathrm{v}_{\mathrm{h}}^{\mathrm{T}} \mathrm{y}_{\mathrm{hj}}^{\mathrm{T}}-\sum_{\mathrm{i}=1}^{2} \mathrm{u}_{\mathrm{i}}^{\mathrm{TS}}\left(\mu_{\mathrm{i}} \mathrm{x}_{\mathrm{ij}}^{\mathrm{S}}\right)-\sum_{\mathrm{i}=3}^{4} \mathrm{u}_{\mathrm{i}}^{\mathrm{T}} \mathrm{x}_{\mathrm{ij}}^{\mathrm{T}} \leq 0, \forall \mathrm{j} \\
0<\mu_{i}<1, \mathrm{i}=1,2 \\
\mathrm{v}_{\mathrm{h}}, \mathrm{u}_{\mathrm{i}} \geq \varepsilon, \forall \mathrm{h}, \forall \mathrm{i} .
\end{gathered}
$$

Research efficiency $\left(R_{k}\right)$ of each $D M U_{k}$ can be evaluated using linear programming:

$$
\operatorname{maxv}_{4}^{\mathrm{R}} \mathrm{y}_{4 \mathrm{k}}^{\mathrm{R}}
$$

Subject to $\sum_{\mathrm{i}=1}^{2} \mathrm{u}_{\mathrm{i}}^{\mathrm{RS}}\left(1-\mu_{i}\right) x_{i k}^{S}+\sum_{\mathrm{i}=5}^{6} \mathrm{u}_{\mathrm{i}}^{\mathrm{R}} \mathrm{x}_{\mathrm{ik}}^{\mathrm{R}}=1$

$$
\begin{gathered}
\mathrm{v}_{4}^{\mathrm{R}} \mathrm{y}_{4 \mathrm{j}}^{\mathrm{R}}-\sum_{\mathrm{i}=1}^{2} \mathrm{u}_{\mathrm{i}}^{\mathrm{RS}}\left(1-\mu_{i}\right) x_{i k}^{S}-\sum_{\mathrm{i}=5}^{6} \mathrm{u}_{\mathrm{i}}^{\mathrm{R}} \mathrm{x}_{\mathrm{ij}}^{\mathrm{R}} \leq 0, \forall \mathrm{j} \\
0<\mu_{i}<1, \mathrm{i}=1,2, \\
\mathrm{v}_{\mathrm{h}}, \mathrm{u}_{\mathrm{i}} \geq \varepsilon, \forall \mathrm{h}, \forall \mathrm{i} .
\end{gathered}
$$

It is known that the overall efficiency of HEIs consists of teaching and research efficiency but not by summing both because both activities have shared inputs. So, to measure the overall efficiency of HEIs, we need to use a joint DEA model that considers shared inputs between the activities. Therefore, the overall efficiency of the $\mathrm{DMU}_{\mathrm{k}}$ can be evaluated using the following linear programming problem and is given by

$$
\max \sum_{\mathrm{h}=1}^{3} \mathrm{v}_{\mathrm{h}}^{\mathrm{T}} \mathrm{y}_{\mathrm{hk}}^{\mathrm{T}}+\mathrm{v}_{4}^{\mathrm{R}} \mathrm{y}_{4 \mathrm{k}}^{\mathrm{R}}
$$

Subject to $\sum_{\mathrm{i}=1}^{2} \mathrm{u}_{\mathrm{i}}^{\mathrm{TS}}\left(\mu_{i} \mathrm{x}_{\mathrm{ik}}^{\mathrm{S}}\right)+\sum_{\mathrm{i}=3}^{4} \mathrm{u}_{\mathrm{i}}^{\mathrm{T}} \mathrm{x}_{i k}^{\mathrm{T}}+\sum_{\mathrm{i}=1}^{2} \mathrm{u}_{\mathrm{i}}^{\mathrm{RS}}\left(1-\mu_{i}\right) x_{i k}^{S}+\sum_{\mathrm{i}=5}^{6} \mathrm{u}_{\mathrm{i}}^{\mathrm{R}} \mathrm{x}_{\mathrm{ik}}^{\mathrm{R}}=1$

$$
\begin{gathered}
\sum_{\mathrm{h}=1}^{3} \mathrm{v}_{\mathrm{h}}^{\mathrm{T}} \mathrm{y}_{\mathrm{hj}}^{\mathrm{T}}+\mathrm{v}_{4}^{\mathrm{R}} \mathrm{y}_{4 \mathrm{j}}^{\mathrm{R}}-\sum_{\mathrm{i}=1}^{2} \mathrm{u}_{\mathrm{i}}^{\mathrm{TS}}\left(\mu_{i} \mathrm{x}_{\mathrm{ij}}^{\mathrm{S}}\right)-\sum_{\mathrm{i}=3}^{4} \mathrm{u}_{\mathrm{i}}^{\mathrm{T}} \mathrm{x}_{i j}^{\mathrm{T}}-\sum_{\mathrm{i}=1}^{2} \mathrm{u}_{\mathrm{i}}^{\mathrm{RS}}\left(1-\mu_{i}\right) x_{i k}^{S}- \\
\sum_{\mathrm{i}=5}^{6} \mathrm{u}_{\mathrm{i}}^{\mathrm{R}} \mathrm{x}_{\mathrm{ij}}^{\mathrm{R}} \leq 0, \forall \mathrm{j} \\
\sum_{\mathrm{h}=1}^{3} \mathrm{v}_{\mathrm{h}}^{\mathrm{T}} \mathrm{y}_{\mathrm{hj}}^{\mathrm{T}}-\sum_{\mathrm{i}=1}^{2} \mathrm{u}_{\mathrm{i}}^{\mathrm{TS}}\left(\mu_{i} \mathrm{x}_{\mathrm{ij}}^{\mathrm{S}}\right)+\sum_{\mathrm{i}=3}^{4} \mathrm{u}_{\mathrm{i}}^{\mathrm{T}} \mathrm{x}_{i j}^{\mathrm{T}} \leq 0, \forall j \\
\mathrm{v}_{4}^{\mathrm{R}} \mathrm{y}_{4 \mathrm{j}}^{\mathrm{R}}-\sum_{\mathrm{i}=1}^{2} \mathrm{u}_{\mathrm{i}}^{\mathrm{RS}}\left(1-\mu_{i}\right) x_{i k}^{S}-\sum_{\mathrm{i}=5}^{6} \mathrm{u}_{\mathrm{i}}^{\mathrm{R}} \mathrm{x}_{\mathrm{ij}}^{\mathrm{R}} \leq 0, \forall \mathrm{j} \\
0<\mu_{i}<1, \mathrm{i}=1,2 . \\
\mathrm{v}_{\mathrm{h}}, \mathrm{u}_{\mathrm{i}} \geq \varepsilon, \forall \mathrm{h}, \forall \mathrm{i} .
\end{gathered}
$$

Each model runs 40 times to calculate the efficiency of all DMUs and each DMU choose input weights and output weights that maximize its efficiency and $\varepsilon$ be the small non zero Archimedean number that makes the value of the weight of $D M U_{k}$ away from zero and taken as an infinitesimal number. The efficiency score of each DMU is between zero and one (inclusive) and the DMU's efficiency score is one that can be taken as efficient, otherwise, it is inefficient. In addition, the DEA model offers guidance for inefficient DMUs on how to boost their efficiency by reducing excess inputs and generating more outputs.

\section{BOOTSTRAPPING TECHNIQUE}

Despite all features in the use of the DEA approach, there are certain restrictions. Some of these are: (i) the problem of serial correlation occurs and it does not give any interpretation of the Data Generating Process (DGP); (ii) it raises uncertainty about the results in the form of inconsistency and invalidity. To deal with all these limitations, we have used a bootstrap technique that gives reliable and statistically significant results and is known as 'bias-free' (Simar \& Wilson 2007, 1998).

As suggested by Simar and Wilson (1998), bootstrap technique is used to eliminate the sensitivity of efficiency scores resulting from (in) efficiency distribution in the sample. It is a re-sampling technique with a replacement for the given observations. Moreover, it generates several estimates that can be used for statistical inference.

The accuracy of the bootstrapped estimation depends on residual model variance and the inherent bias of the bootstrap process, and both factors vary with sample size. The residual variance is the source of bootstrapping variability. Bias in bootstrap is any variance value due to the random re-sampling process in the bootstrap. Particularly, if the sample size is not large enough and the results are scattered, the impact of bias can be spread out. Consequently, amending bias to bootstrap adjusts the distribution of the estimator to its predicted value.

Consider, a set of observations $X=\left\{\left(x_{i}, y_{i}\right) \quad i=1,2\right.$, $\ldots, n\}$ refers to ' $n$ ' production units and the algorithm of bootstrap technique is summarized by the following steps:

i. Use the DEA approach to estimate $\hat{\theta}_{k}$ for each $\left(x_{k}, y_{k}\right)$, $k=1,2, \ldots, n$.

ii. Generate a random smooth sample of size ' $n$ ' from $\hat{\theta}_{k}$ $k=1,2, \ldots, n$ to provide $\theta_{1 b}{ }^{*}, \theta_{2 b}{ }^{*}, \ldots, \theta_{n b}{ }^{*}$.

iii. Obtain $\left.X_{b}^{*}=\left\{x_{i}, y_{i b}^{*}\right): i=1,2, \ldots, n\right\}$ where $y_{i b}^{*}=\left(\frac{\theta_{i}}{\theta_{i b}^{*}}\right)$ $y_{i}=1,2, \ldots, n$.

iv. Compute $\hat{\theta}_{k b}^{*}$ of $\hat{\theta}_{k}$ for $k=1,2, \ldots, n$ by solving

$$
\hat{\theta}_{k b}^{*}=\max \left\{\theta: \theta y_{k} \geq \sum_{i=1}^{n} \lambda_{i} y_{i b}^{*} ; x_{k} \leq \sum_{i=1}^{n} \lambda_{i} x_{i}, \theta>\right.
$$$$
\left.0 ; \sum_{i=1}^{n} \lambda_{i}=1 ; \lambda_{i} \geq 0, \forall i\right\}
$$ 
v. Repeat steps ii-iv B times to obtain a set of estimates $\left\{\hat{\theta}_{k b}^{*}, b=1,2, \ldots, B\right\}$ for $k=1,2, \ldots, n$.

When ' $B$ ' $=1000$, it ensures sufficient convergence of the confidence interval (Hall 1986).

The result of teaching efficiency scores of the bootstrap exercise for $\mathrm{B}=1000$ is presented in Table 1 . Column 1 displays the HEI number, while the original DEA efficiency scores, the bias-corrected efficiency scores, the bootstrap bias estimate, and the median bootstrap values are given in columns 2-5. Columns 6-9 give $95 \%$ confidence intervals of the bias-corrected efficiency scores. Since the median of $\tilde{\theta}_{k b}^{*}$ is close to $\tilde{\theta}_{k}$ in each case, the two confidence interval sets are similar. When the samples are biased like DEA efficiency scores, the median offers a more robust measure of location.
Similarly, the results of research efficiency scores and overall efficiency scores of the bootstrap exercise for $\mathrm{B}=1000$ are presented in Tables 2 and 3, respectively. From Tables 1-3, the results indicated that some of the HEIs are efficient on the basis of the original DEA efficiency scores $\left(\hat{\theta}_{k}\right)$. However, they become inefficient after eliminating the sensitivity of efficiency scores of these institutions. For instance, the institutions are $D M U_{15}$ and $\mathrm{DMU}_{36}$ in teacher efficiency, $D M U_{35}$ in research efficiency and $D M U_{15}, D M U_{30}, D M U_{36}$ and $\mathrm{DMU}_{38}$ in overall efficiency. Moreover, due to the bias of the efficiency scores, the institutions' original efficiency score $\left(\hat{\theta}_{k}\right)$ is greater than or equal to the institutions' biascorrected efficiency $\operatorname{scores}\left(\tilde{\theta}_{k}\right)$. Therefore, bootstrapping approach is very useful for calculating the efficiency of a DMU using a non-parametric approach.

TABLE 1. Bootstrap of teaching efficiency scores

\begin{tabular}{|c|c|c|c|c|c|c|c|c|}
\hline \multirow{2}{*}{$\mathrm{k}$} & \multirow{2}{*}{$\hat{\theta}_{k}$} & \multirow{2}{*}{$\tilde{\theta}_{k}$} & \multirow{2}{*}{ bias $_{k}$} & \multirow{2}{*}{ Median of $\tilde{\theta}_{k b}^{*}$} & & $97.5 \%$ & \multirow{2}{*}{$\begin{array}{l}2.5 \% \\
\text { Centered on }\end{array}$} & \multirow{2}{*}{$\begin{array}{c}97.5 \% \\
\tilde{\theta}_{k}\end{array}$} \\
\hline & & & & & \multicolumn{2}{|c|}{ Bias Corrected } & & \\
\hline 1 & 0.3906 & 0.3656 & 0.0250 & 0.3542 & 0.3425 & 0.4010 & 0.3436 & 0.4142 \\
\hline 2 & 0.6272 & 0.5559 & 0.0713 & 0.5497 & 0.5370 & 0.6341 & 0.5394 & 0.6487 \\
\hline 3 & 0.3976 & 0.3854 & 0.0122 & 0.3814 & 0.3776 & 0.4035 & 0.3790 & 0.4135 \\
\hline 4 & 1.0000 & 1.0000 & 0.0083 & 0.9996 & 0.9926 & 1.0112 & 0.9951 & 1.0166 \\
\hline 5 & 1.0000 & 1.0000 & 0.0015 & 1.0000 & 1.0000 & 1.0035 & 0.9998 & 1.0091 \\
\hline 6 & 0.9697 & 0.9474 & 0.0223 & 0.9395 & 0.9239 & 0.9754 & 0.9256 & 0.9794 \\
\hline 7 & 0.4520 & 0.3919 & 0.0601 & 0.3892 & 0.3744 & 0.4698 & 0.3768 & 0.4738 \\
\hline 8 & 1.0000 & 1.0000 & 0.0014 & 1.0000 & 0.9964 & 1.0029 & 0.9988 & 1.0079 \\
\hline 9 & 0.3830 & 0.3586 & 0.0244 & 0.3503 & 0.3432 & 0.3911 & 0.3469 & 0.4091 \\
\hline 10 & 0.7909 & 0.7787 & 0.0145 & 0.7719 & 0.7688 & 0.8063 & 0.7702 & 0.8163 \\
\hline 11 & 0.8531 & 0.8109 & 0.0422 & 0.8092 & 0.7952 & 0.8619 & 0.7984 & 0.8698 \\
\hline 12 & 0.4119 & 0.3798 & 0.0321 & 0.3708 & 0.3669 & 0.4179 & 0.3689 & 0.4225 \\
\hline 13 & 0.3713 & 0.3481 & 0.0232 & 0.3466 & 0.3325 & 0.3836 & 0.3348 & 0.3953 \\
\hline 14 & 0.4216 & 0.4029 & 0.0187 & 0.4009 & 0.3977 & 0.4296 & 0.3987 & 0.4327 \\
\hline 15 & 1.0000 & 0.9728 & 0.0288 & 0.9706 & 0.9684 & 1.0176 & 0.9702 & 1.0311 \\
\hline 16 & 0.9956 & 0.9798 & 0.0158 & 0.9732 & 0.9657 & 0.9998 & 0.9688 & 1.0091 \\
\hline 17 & 1.0000 & 1.0000 & 0.0049 & 1.0000 & 1.0000 & 1.0077 & 1.0000 & 1.0120 \\
\hline 18 & 0.6832 & 0.6097 & 0.0735 & 0.6070 & 0.5971 & 0.6930 & 0.6007 & 0.7053 \\
\hline 19 & 0.4352 & 0.4180 & 0.0172 & 0.4156 & 0.4029 & 0.4405 & 0.4066 & 0.4517 \\
\hline 20 & 0.8717 & 0.8257 & 0.0460 & 0.8230 & 0.8142 & 0.8780 & 0.8173 & 0.8834 \\
\hline 21 & 0.4280 & 0.3993 & 0.0287 & 0.3974 & 0.3830 & 0.4306 & 0.3869 & 0.4402 \\
\hline 22 & 0.3001 & 0.2829 & 0.0172 & 0.2801 & 0.2782 & 0.3057 & 0.2748 & 0.3125 \\
\hline 23 & 0.4492 & 0.3974 & 0.0518 & 0.3948 & 0.3826 & 0.4563 & 0.3856 & 0.4677 \\
\hline 24 & 0.9403 & 0.9230 & 0.0173 & 0.9212 & 0.9145 & 0.9475 & 0.9146 & 0.9555 \\
\hline 25 & 0.6712 & 0.6082 & 0.0630 & 0.6069 & 0.5987 & 0.6741 & 0.6014 & 0.6874 \\
\hline 26 & 0.4391 & 0.4252 & 0.0139 & 0.4228 & 0.4182 & 0.4427 & 0.4147 & 0.4501 \\
\hline
\end{tabular}




\begin{tabular}{|c|c|c|c|c|c|c|c|c|}
\hline 27 & 0.3325 & 0.3100 & 0.0225 & 0.3091 & 0.2960 & 0.3375 & 0.2985 & 0.3451 \\
\hline 28 & 1.0000 & 1.0000 & 0.0089 & 1.0000 & 1.0000 & 1.0112 & 1.0000 & 1.0169 \\
\hline 29 & 0.5533 & 0.4893 & 0.0640 & 0.4869 & 0.4724 & 0.5587 & 0.4768 & 0.5620 \\
\hline 30 & 0.9551 & 0.9510 & 0.0041 & 0.9501 & 0.9479 & 0.9583 & 0.9498 & 0.9678 \\
\hline 31 & 0.6226 & 0.5854 & 0.0372 & 0.5841 & 0.5789 & 0.6257 & 0.5804 & 0.6396 \\
\hline 32 & 0.7764 & 0.7660 & 0.0104 & 0.7646 & 0.7548 & 0.7779 & 0.7577 & 0.7861 \\
\hline 33 & 1.0000 & 1.0000 & 0.0031 & 0.9994 & 0.9925 & 1.0066 & 0.9974 & 1.0102 \\
\hline 34 & 0.6544 & 0.6123 & 0.0421 & 0.6112 & 0.6081 & 0.6575 & 0.6098 & 0.6659 \\
\hline 35 & 1.0000 & 1.0000 & 0.0001 & 0.9999 & 0.9986 & 1.0002 & 0.9992 & 1.0033 \\
\hline 36 & 1.0000 & 0.9864 & 0.0184 & 0.9849 & 0.9822 & 1.0023 & 0.9866 & 1.0099 \\
\hline 37 & 0.9696 & 0.9587 & 0.0109 & 0.9565 & 0.9482 & 0.9718 & 0.9514 & 0.9825 \\
\hline 38 & 0.9930 & 0.9831 & 0.0099 & 0.9820 & 0.9791 & 0.9954 & 0.9814 & 1.0071 \\
\hline 39 & 0.4384 & 0.3978 & 0.0406 & 0.3954 & 0.3908 & 0.4416 & 0.3945 & 0.4476 \\
\hline 40 & 0.7222 & 0.7031 & 0.0191 & 0.7019 & 0.6984 & 0.7279 & 0.7007 & 0.7361 \\
\hline
\end{tabular}

TABLE 2. Bootstrap of research efficiency scores

\begin{tabular}{|c|c|c|c|c|c|c|c|c|}
\hline \multirow{3}{*}{$\begin{array}{l}\mathrm{k} \\
1\end{array}$} & \multirow{3}{*}{$\begin{array}{c}\hat{\theta}_{k} \\
0.0888\end{array}$} & \multirow{3}{*}{$\begin{array}{c}\tilde{\theta}_{k} \\
0.0734\end{array}$} & \multirow{3}{*}{$\begin{array}{c}\text { bias }_{k} \\
0.0154\end{array}$} & \multirow{3}{*}{$\begin{array}{c}\text { Median of } \tilde{\theta}_{k b}^{*} \\
0.0726\end{array}$} & \multirow{2}{*}{\multicolumn{2}{|c|}{$\begin{array}{l}2.5 \% \quad 97.5 \% \\
\text { Bias Corrected }\end{array}$}} & \multirow{2}{*}{\multicolumn{2}{|c|}{ Centered on $\tilde{\theta}_{k}$}} \\
\hline & & & & & & & & \\
\hline & & & & & 0.0718 & 0.0892 & 0.0725 & 0.0945 \\
\hline 2 & 0.2987 & 0.2755 & 0.0232 & 0.2741 & 0.2725 & 0.30513 & 0.2748 & 0.3115 \\
\hline 3 & 0.7931 & 0.7816 & 0.0115 & 0.7808 & 0.7802 & 0.7963 & 0.7829 & 0.8063 \\
\hline 4 & 0.2871 & 0.2416 & 0.0455 & 0.2405 & 0.2399 & 0.2909 & 0.2419 & 0.3000 \\
\hline 5 & 0.5203 & 0.5083 & 0.0120 & 0.5067 & 0.5053 & 0.5260 & 0.5084 & 0.5335 \\
\hline 6 & 1.0000 & 1.0000 & 0.0032 & 1.0000 & 1.0000 & 1.0069 & 1.0000 & 1.0143 \\
\hline 7 & 0.8413 & 0.8317 & 0.0096 & 0.8306 & 0.8294 & 0.8480 & 0.8310 & 0.8526 \\
\hline 8 & 1.0000 & 1.0000 & 0.0015 & 0.9994 & 0.9986 & 1.0022 & 0.9992 & 1.0091 \\
\hline 9 & 0.5402 & 0.5274 & 0.0128 & 0.5266 & 0.5233 & 0.5474 & 0.5280 & 0.5542 \\
\hline 10 & 0.5178 & 0.4824 & 0.0354 & 0.4818 & 0.4793 & 0.5211 & 0.4816 & 0.5284 \\
\hline 11 & 0.5076 & 0.4691 & 0.0385 & 0.4672 & 0.4657 & 0.5145 & 0.4695 & 0.5168 \\
\hline 12 & 0.2858 & 0.2181 & 0.0677 & 0.2154 & 0.2099 & 0.2896 & 0.2133 & 0.2946 \\
\hline 13 & 0.5083 & 0.4735 & 0.0348 & 0.4729 & 0.4714 & 0.5127 & 0.4732 & 0.5199 \\
\hline 14 & 0.4856 & 0.4643 & 0.0213 & 0.4635 & 0.4625 & 0.4901 & 0.4638 & 0.4997 \\
\hline 15 & 0.3944 & 0.3605 & 0.0339 & 0.3598 & 0.3584 & 0.3978 & 0.3601 & 0.4078 \\
\hline 16 & 0.4000 & 0.3695 & 0.0305 & 0.3684 & 0.3664 & 0.4042 & 0.3681 & 0.4133 \\
\hline 17 & 0.4144 & 0.3855 & 0.0289 & 0.3847 & 0.3815 & 0.4183 & 0.3836 & 0.4274 \\
\hline 18 & 0.4046 & 0.3670 & 0.0376 & 0.3661 & 0.3643 & 0.4088 & 0.3659 & 0.4188 \\
\hline 19 & 0.3031 & 0.2410 & 0.0621 & 0.2403 & 0.2389 & 0.3087 & 0.2306 & 0.3112 \\
\hline 20 & 0.3298 & 0.2785 & 0.0513 & 0.2776 & 0.2739 & 0.3344 & 0.2760 & 0.3407 \\
\hline 21 & 0.3427 & 0.3070 & 0.0357 & 0.3059 & 0.3030 & 0.3485 & 0.3061 & 0.3548 \\
\hline 22 & 0.4993 & 0.4776 & 0.0217 & 0.4663 & 0.4729 & 0.5036 & 0.4786 & 0.5165 \\
\hline 23 & 0.4406 & 0.4255 & 0.0151 & 0.4247 & 0.4184 & 0.4468 & 0.4217 & 0.4528 \\
\hline 24 & 0.3923 & 0.3695 & 0.0228 & 0.3689 & 0.3658 & 0.3956 & 0.3691 & 0.4056 \\
\hline
\end{tabular}




\begin{tabular}{|c|c|c|c|c|c|c|c|c|}
\hline 25 & 1.0000 & 1.0000 & 0.0035 & 1.0000 & 1.0000 & 1.0079 & 0.9997 & 1.0144 \\
\hline 26 & 0.5647 & 0.5427 & 0.0220 & 0.5419 & 0.5384 & 0.5681 & 0.5411 & 0.5716 \\
\hline 27 & 0.4742 & 0.4420 & 0.0322 & 0.4408 & 0.4367 & 0.4783 & 0.4405 & 0.4856 \\
\hline 28 & 0.5735 & 0.5614 & 0.0121 & 0.5600 & 0.5569 & 0.5759 & 0.5698 & 0.5875 \\
\hline 29 & 1.0000 & 1.0000 & 0.0028 & 0.9992 & 0.9960 & 1.0056 & 0.9995 & 1.0088 \\
\hline 30 & 0.6174 & 0.6020 & 0.0154 & 0.6011 & 0.5938 & 0.6290 & 0.5986 & 0.6392 \\
\hline 31 & 1.0000 & 1.0000 & 0.0054 & 1.0000 & 1.0000 & 1.0096 & 1.0000 & 1.0172 \\
\hline 32 & 0.5463 & 0.5286 & 0.0177 & 0.5277 & 0.5216 & 0.5499 & 0.5259 & 0.5596 \\
\hline 33 & 1.0000 & 1.0000 & 0.0045 & 0.9993 & 0.9964 & 1.0090 & 0.9987 & 1.0157 \\
\hline 34 & 1.0000 & 1.0000 & 0.0026 & 1.0000 & 1.0000 & 1.0064 & 1.0000 & 1.00112 \\
\hline 35 & 1.0000 & 0.9902 & 0.0130 & 0.9895 & 0.9853 & 1.0074 & 0.9886 & 1.0158 \\
\hline 36 & 0.4900 & 0.4555 & 0.0345 & 0.4537 & 0.4501 & 0.4969 & 0.4538 & 0.5069 \\
\hline 37 & 0.1534 & 0.1283 & 0.0251 & 0.1269 & 0.1229 & 0.1598 & 0.1277 & 0.1687 \\
\hline 38 & 0.3342 & 0.3131 & 0.0211 & 0.3116 & 0.3079 & 0.3387 & 0.3118 & 0.3452 \\
\hline 39 & 0.5484 & 0.5328 & 0.0156 & 0.5320 & 0.5275 & 0.5576 & 0.5305 & 0.5688 \\
\hline 40 & 0.3120 & 0.2740 & 0.0380 & 0.2708 & 0.2686 & 0.3161 & 0.2713 & 0.3243 \\
\hline
\end{tabular}

TABLE 3. Bootstrap of overall efficiency scores

\begin{tabular}{|c|c|c|c|c|c|c|c|c|}
\hline \multirow{3}{*}{$\frac{\mathrm{k}}{1}$} & \multirow{3}{*}{$\begin{array}{c}\hat{\theta}_{k} \\
0.4095\end{array}$} & \multirow{3}{*}{$\begin{array}{c}\tilde{\theta}_{k} \\
0.3745\end{array}$} & \multirow{3}{*}{$\begin{array}{c}\text { bias }_{k} \\
0.0350\end{array}$} & \multirow{3}{*}{$\begin{array}{c}\text { Median of } \tilde{\theta}_{k b}^{*} \\
0.3704\end{array}$} & \multirow{2}{*}{\multicolumn{2}{|c|}{$\begin{array}{l}2.5 \% \quad 97.5 \% \\
\text { Bias Corrected }\end{array}$}} & $2.5 \%$ & $97.5 \%$ \\
\hline & & & & & & & \multicolumn{2}{|c|}{ Centered on $\tilde{\theta}_{k}$} \\
\hline & & & & & 0.3625 & 0.4175 & 0.3654 & 0.4236 \\
\hline 2 & 0.5797 & 0.5615 & 0.0182 & 0.5601 & 0.5547 & 0.5835 & 0.5588 & 0.5973 \\
\hline 3 & 0.8069 & 0.7922 & 0.0147 & 0.7916 & 0.7850 & 0.8111 & 0.7882 & 0.8197 \\
\hline 4 & 1.0000 & 1.0000 & 0.0083 & 1.0004 & 0.9982 & 1.0133 & 0.9993 & 1.0166 \\
\hline 5 & 1.0000 & 1.0000 & 0.0064 & 1.0000 & 1.0000 & 1.0089 & 1.0000 & 1.0145 \\
\hline 6 & 1.0000 & 1.0000 & 0.0029 & 1.0000 & 1.0000 & 1.0045 & 1.0000 & 1.0074 \\
\hline 7 & 0.8512 & 0.8411 & 0.0101 & 0.8402 & 0.8342 & 0.8580 & 0.8392 & 0.8678 \\
\hline 8 & 1.0000 & 1.0000 & 0.0005 & 0.9998 & 0.9984 & 1.0020 & 0.9991 & 1.0045 \\
\hline 9 & 0.5435 & 0.5364 & 0.0071 & 0.5347 & 0.5315 & 0.5473 & 0.5339 & 0.5514 \\
\hline 10 & 0.7937 & 0.7792 & 0.0145 & 0.7742 & 0.7718 & 0.8063 & 0.7744 & 0.8152 \\
\hline 11 & 0.8246 & 0.8148 & 0.0098 & 0.8116 & 0.8092 & 0.8280 & 0.8122 & 0.8374 \\
\hline 12 & 0.5600 & 0.5365 & 0.0235 & 0.5322 & 0.5297 & 0.5685 & 0.5335 & 0.5801 \\
\hline 13 & 0.5021 & 0.4760 & 0.0261 & 0.4690 & 0.4688 & 0.5094 & 0.4739 & 0.5177 \\
\hline 14 & 0.4980 & 0.4750 & 0.0230 & 0.4701 & 0.4667 & 0.5041 & 0.4725 & 0.5187 \\
\hline 15 & 1.0000 & 0.9741 & 0.0173 & 0.9716 & 0.9688 & 1.0097 & 0.9722 & 1.0154 \\
\hline 16 & 0.9915 & 0.9798 & 0.0117 & 0.9720 & 0.9701 & 0.9974 & 0.9754 & 1.0010 \\
\hline 17 & 1.0000 & 1.0000 & 0.0042 & 1.0000 & 1.0000 & 1.0066 & 1.0000 & 1.0125 \\
\hline 18 & 0.8190 & 0.8108 & 0.0082 & 0.8076 & 0.7955 & 0.8242 & 0.7998 & 0.8334 \\
\hline 19 & 0.6151 & 0.5912 & 0.0239 & 0.5888 & 0.6066 & 0.6182 & 0.6099 & 0.6292 \\
\hline 20 & 0.9944 & 0.9756 & 0.0188 & 0.9701 & 0.9694 & 1.0037 & 0.9725 & 1.0116 \\
\hline 21 & 0.5960 & 0.5847 & 0.0113 & 0.5812 & 0.5785 & 0.6026 & 0.5814 & 0.6110 \\
\hline 22 & 0.6983 & 0.6607 & 0.0376 & 0.6574 & 0.6545 & 0.7025 & 0.6586 & 0.7192 \\
\hline
\end{tabular}




\begin{tabular}{|c|c|c|c|c|c|c|c|c|}
\hline 23 & 0.5239 & 0.5095 & 0.0144 & 0.5070 & 0.5001 & 0.5291 & 0.5059 & 0.5382 \\
\hline 24 & 0.9535 & 0.9312 & 0.0223 & 0.9285 & 0.9239 & 0.9574 & 0.9287 & 0.9671 \\
\hline 25 & 1.0000 & 1.0000 & 0.0088 & 1.0000 & 1.0000 & 1.0123 & 1.0000 & 1.0198 \\
\hline 26 & 0.8601 & 0.8050 & 0.0551 & 0.7966 & 0.7852 & 0.8798 & 0.7949 & 0.8912 \\
\hline 27 & 0.8703 & 0.6012 & 0.0889 & 0.8005 & 0.6649 & 0.8222 & 0.6268 & 0.8222 \\
\hline 28 & 1.0000 & 1.0000 & 0.0079 & 0.9977 & 0.9912 & 1.0127 & 0.9983 & 1.0175 \\
\hline 29 & 1.0000 & 1.0000 & 0.0046 & 0.9992 & 0.9953 & 1.0088 & 0.9993 & 1.0112 \\
\hline 30 & 1.0000 & 0.9912 & 0.0470 & 0.9860 & 0.9817 & 1.0440 & 0.9877 & 1.0594 \\
\hline 31 & 1.0000 & 1.0000 & 0.0163 & 0.9943 & 0.9951 & 1.0156 & 0.9987 & 1.0226 \\
\hline 32 & 0.8500 & 0.7755 & 0.0745 & 0.7689 & 0.7646 & 0.8631 & 0.7694 & 0.8763 \\
\hline 33 & 1.0000 & 1.0000 & 0.0021 & 0.9994 & 0.9966 & 1.0042 & 0.9990 & 1.0088 \\
\hline 34 & 1.0000 & 1.0000 & 0.0089 & 0.9952 & 0.9923 & 1.0122 & 0.9949 & 1.0202 \\
\hline 35 & 1.0000 & 1.0000 & 0.0055 & 0.9978 & 0.9933 & 1.0055 & 0.9967 & 1.0110 \\
\hline 36 & 1.0000 & 0.9872 & 0.0201 & 0.9801 & 0.9815 & 1.0211 & 0.9476 & 1.0283 \\
\hline 37 & 0.9713 & 0.9594 & 0.0119 & 0.9534 & 0.9552 & 0.9788 & 0.9584 & 0.9865 \\
\hline 38 & 1.0000 & 0.9901 & 0.0380 & 0.9802 & 0.9846 & 1.3761 & 0.9885 & 1.4462 \\
\hline 39 & 0.8219 & 0.8068 & 0.0151 & 0.8036 & 0.8010 & 0.8268 & 0.8047 & 0.8393 \\
\hline 40 & 0.7709 & 0.7427 & 0.0282 & 0.7419 & 0.7382 & 0.7765 & 0.7413 & 0.7885 \\
\hline
\end{tabular}

\section{RESULTS}

This section discusses the results of the teaching efficiency, research efficiency, and overall efficiency of the HEIs.

\section{Descriptive statistics and analysis}

Table 4 illustrates the descriptive statistics of inputs and outputs of 40 Pakistani HEIs. During one year (20172018), 40 HEIs awarded degrees to 62168 and published 9737 research papers, books, and conferences. These outputs were accomplished by using 19011 faculty members, 129 libraries, 1664 laboratories, supervising 376 $\mathrm{PhD}$ theses, and funded around 926.2 million Pakistan rupees.

\section{Relative efficiency of Higher Educations Institutions}

The relative efficiency score of HEIs was computed using the output-oriented technical efficiency approach. The teaching efficiency, research efficiency, and overall (joint) efficiency of 40 HEIs under observations are given in Table 5.

The relative efficiency score for each HEI lies between zero and one (inclusive). An institution which is its relative efficiency score is one as an efficient institution, otherwise, it is an inefficient institution, and one is the threshold value for an efficient institution (Banker et al.1984). From Table 3, 7 out of 40 HEIs are efficient in teaching with a mean score of 0.6586 , a standard deviation of 0.2845 , and the lowest score of 0.2829 . However, only 14 HEIs scored their teaching efficiency below 0.5 . While 7 out of 40 HEIs are efficient in research with a mean score of 0.5325 , a standard deviation of 0.2779 , and the lowest score of 0.0734. 17 HEIs could cross above the threshold of 0.5 but a high dispersion among efficiency scores of the institutions in research activity has been found. Thus, HEIs were performed better in teaching than in research, thus, seem more heterogeneous in research due to high dispersion. Moreover, 12 out of 40 HEIs are efficient in their overall efficiency with a mean score of 0.8216 , a standard deviation of 0.1982 , and the lowest score is 0.3745 which is greater than the minimum score of teaching and research activities. This implies that these activities can be viewed as a joint process for the higher education system. Therefore, HEI that carries out both activities joint is more productive than performing a single activity in isolation. To identify easily the level of performance of the institutions with respect to each activity, the efficiency scores of HEIs describe graphically in Figure 2.

According to the direction of the DEA model, analysis of projections and slacks can help in determining the potential improvement in efficiency scores for the inefficient DMUs. In the context of higher education, we focus on the analysis of projection. The improvement 
targets provide a direction on how the institutions improve their performance. For instance, should increase graduates from 1350 to 3604 , average grade results from 3.10 to 3.27 , the graduate rate from $12.27 \%$ to $47.48 \%$, and number of publications from 46 to 297; should increase its degree awarded students from 308 to 741 , average grade result from 3.4 to 3.54 , the graduate rate from $25.61 \%$ to $72.43 \%$, and the number of publications from 140 to 146. Even though we concentrated on the output projection, the slack of inputs allows the HEI to assess to what extent the inputs have been misused due to excessive existing resources and lets the institution provide a guideline on the efficient use of the resources. Therefore, these projections and slacks enable the institutions to design guidelines and policies that can improve performance, modified policies, and decisionmaking in order to enhance the efficiency of the institution based on the empirical finding. It converts into action rely on the empirical finding but not on the opinions and views of the institutions' faculty or educational administrators. These improvement targets for inefficient HEIs are summarized in Table 6.

We suggested that the inefficient HEIs improve their research productivity when the institutions work in collaboration with industries on a mutually beneficial relationship and use relevant publication metrics for promotions. Moreover, the faculty members could have a research network on their specializations. Similarly, to improve students' performance, the teachers could motivate their students to work in a group and use the instructional facilities while teaching. Moreover, the institutions could be well equipped because it motivates the students to have better academic performance and effective learning.

TABLE 4. Descriptive statistics of 40 HEIs during the period of 2017-2018

\begin{tabular}{|c|c|c|c|c|c|c|}
\hline Variable & Description of variables & Sum & Mean & SD & Min & $\operatorname{Max}$ \\
\hline $\mathrm{x}_{1}$ & Number of faculty members & 19011 & 475.28 & 586.63 & 35 & 3193 \\
\hline $\mathrm{x}_{2}$ & Number of laboratories & 1664 & 41.6 & 66.7 & 3 & 297 \\
\hline $\mathrm{x}_{3}$ & Number of libraries & 129 & 3.23 & 1.98 & 1 & 7 \\
\hline $\mathrm{x}_{4}$ & Number of enrollment course taught students & 278637 & 6965.93 & 8279.15 & 620 & 38058 \\
\hline $\mathrm{x}_{5}$ & Number of $\mathrm{PhD}$ thesis supervised & 376 & 9.4 & 8.05 & 4 & 35 \\
\hline$x_{6}$ & Amount of research grant (in millions Pakistani rupees) & 926.2 & 23.15 & 33.9 & 0.5 & 170.04 \\
\hline $\mathrm{y}_{1}$ & Number of graduated students from course taught & 62168 & 1554.2 & 1531.2 & 203 & 6707 \\
\hline$y_{2}$ & Average graduates' result (CGPA) & - & 3.19 & 0.12 & 2.9 & 3.43 \\
\hline$y_{3}$ & Graduate rate & - & 25.42 & 13.53 & 7 & 62.02 \\
\hline $\mathrm{y}_{4}$ & $\begin{array}{l}\text { Number of published research papers, books, and } \\
\text { conferences }\end{array}$ & 9737 & 243.43 & 275.63 & 3 & 1500 \\
\hline
\end{tabular}


TABLE 5. Relative efficiency scores of HEIs

\begin{tabular}{|c|c|c|c|}
\hline DMU & Teaching efficiency scores & Research efficiency scores & Overall efficiency scores \\
\hline 1 & 0.3656 & 0.0734 & 0.3745 \\
\hline 2 & 0.5559 & 0.2755 & 0.5615 \\
\hline 3 & 0.3854 & 0.7816 & 0.7922 \\
\hline 4 & 1.0000 & 0.2416 & 1.0000 \\
\hline 5 & 1.0000 & 0.5083 & 1.0000 \\
\hline 6 & 0.9474 & 1.0000 & 1.0000 \\
\hline 7 & 0.3919 & 0.8317 & 0.8411 \\
\hline 8 & 1.0000 & 1.0000 & 1.0000 \\
\hline 9 & 0.3586 & 0.5274 & 0.5364 \\
\hline 10 & 0.7787 & 0.4824 & 0.7792 \\
\hline 11 & 0.8109 & 0.4691 & 0.8148 \\
\hline 12 & 0.3798 & 0.2181 & 0.5365 \\
\hline 13 & 0.3481 & 0.4735 & 0.4760 \\
\hline 14 & 0.4029 & 0.4643 & 0.4750 \\
\hline 15 & 0.9728 & 0.3605 & 0.9741 \\
\hline 16 & 0.9798 & 0.3695 & 0.9798 \\
\hline 17 & 1.0000 & 0.3855 & 1.0000 \\
\hline 18 & 0.6097 & 0.3670 & 0.8108 \\
\hline 19 & 0.4180 & 0.2410 & 0.5912 \\
\hline 20 & 0.8257 & 0.2785 & 0.9756 \\
\hline 21 & 0.3993 & 0.3070 & 0.5847 \\
\hline 22 & 0.2829 & 0.4776 & 0.6607 \\
\hline 23 & 0.3974 & 0.4255 & 0.5095 \\
\hline 24 & 0.9230 & 0.3695 & 0.9312 \\
\hline 25 & 0.6082 & 1.0000 & 1.0000 \\
\hline 26 & 0.4252 & 0.5427 & 0.8050 \\
\hline 27 & 0.3100 & 0.4420 & 0.6012 \\
\hline 28 & 1.0000 & 0.5614 & 1.0000 \\
\hline 29 & 0.4893 & 1.0000 & 1.0000 \\
\hline 30 & 0.9510 & 0.6020 & 0.9912 \\
\hline 31 & 0.5854 & 1.0000 & 1.0000 \\
\hline 32 & 0.7660 & 0.5286 & 0.7755 \\
\hline 33 & 1.0000 & 1.0000 & 1.0000 \\
\hline 34 & 0.6123 & 1.0000 & 1.0000 \\
\hline 35 & 1.0000 & 0.9902 & 1.0000 \\
\hline 36 & 0.9864 & 0.4555 & 0.9872 \\
\hline 37 & 0.9587 & 0.1283 & 0.9594 \\
\hline 38 & 0.9831 & 0.3131 & 0.9901 \\
\hline 39 & 0.3978 & 0.5328 & 0.8068 \\
\hline 40 & 0.7031 & 0.2740 & 0.7427 \\
\hline
\end{tabular}


TABLE 6. Improvement targets of inefficient HEIs

\begin{tabular}{|c|c|c|c|c|c|c|c|c|c|c|}
\hline $\mathrm{DMU}$ & $\mathrm{x}_{1}$ & $x_{2}$ & $x_{3}$ & $\mathrm{x}_{4}$ & $\mathrm{X}_{5}$ & $X_{6}$ & $\mathrm{Y}_{1}$ & $\mathrm{Y}_{2}$ & $Y_{3}$ & $\mathrm{Y}_{4}$ \\
\hline 1 & 3249 & 184 & 2 & 7590 & 10 & 15 & 3604 & 3.27 & 47.48 & 297 \\
\hline 2 & 2715 & 70 & 1 & 1023 & 15 & 12.65 & 741 & 3.45 & 72.43 & 146 \\
\hline 3 & 4256 & 445 & 2 & 8953 & 20 & 35.66 & 6323 & 3.25 & 70.62 & 767 \\
\hline 7 & 3634 & 229 & 4 & 13221 & 5 & 2.00 & 9102 & 3.22 & 68.84 & 258 \\
\hline 9 & 2026 & 137 & 2 & 4263 & 2 & 0.88 & 2350 & 3.43 & 55.12 & 72 \\
\hline 10 & 1378 & 17 & 3 & 4123 & 3 & 9.50 & 2217 & 3.41 & 53.77 & 102 \\
\hline 11 & 1730 & 32 & 2 & 2896 & 10 & 10.8 & 1038 & 3.4 & 35.84 & 249 \\
\hline 12 & 4640 & 864 & 4 & 6269 & 12 & 39.25 & 3402 & 3.29 & 54.26 & 786 \\
\hline 13 & 4248 & 708 & 5 & 6191 & 12 & 28.32 & 3065 & 3.36 & 51.12 & 733 \\
\hline 14 & 21570 & 954 & 7 & 29405 & 35 & 134.71 & 21514 & 3.25 & 63.33 & 1500 \\
\hline 15 & 2688 & 67 & 1 & 1557 & 13 & 16.78 & 1040 & 3.28 & 63.79 & 221 \\
\hline 16 & 3952 & 160 & 3 & 8038 & 15 & 17.45 & 3491 & 3.31 & 43.43 & 416 \\
\hline 18 & 6577 & 1266 & 5 & 11303 & 24 & 59.82 & 8270 & 3.22 & 73.16 & 1059 \\
\hline 19 & 984 & 88 & 1 & 1500 & 4 & 7.06 & 887 & 3.31 & 59.13 & 81 \\
\hline 20 & 492 & 50 & 1 & 777 & 2 & 3.57 & 519 & 3.35 & 66.79 & 29 \\
\hline 21 & 934 & 136 & 1 & 1569 & 2 & 7.72 & 804 & 3.28 & 51.24 & 109 \\
\hline 22 & 3506 & 176 & 4 & 7689 & 19 & 20.93 & 1703 & 3.23 & 22.14 & 705 \\
\hline 23 & 3314 & 265 & 3 & 5894 & 14 & 22.68 & 3514 & 3.36 & 59.61 & 529 \\
\hline 24 & 2022 & 168 & 1 & 4094 & 7 & 11.84 & 2590 & 3.31 & 63.26 & 247 \\
\hline 26 & 958 & 164 & 1 & 1414 & 2 & 7.71 & 910 & 3.47 & 64.35 & 141 \\
\hline 27 & 1652 & 192 & 1 & 3550 & 4 & 10.70 & 1926 & 3.34 & 54.25 & 257 \\
\hline 30 & 3818 & 152 & 4 & 8527 & 15 & 20.29 & 3354 & 3.23 & 39.34 & 422 \\
\hline 32 & 1938 & 24 & 3 & 3490 & 6 & 12.14 & 1960 & 3.32 & 56.16 & 136 \\
\hline 36 & 1013 & 28 & 1 & 2545 & 7 & 7.98 & 1424 & 3.29 & 55.95 & 113 \\
\hline 37 & 349 & 24 & 1 & 726 & 1 & 2.28 & 333 & 3.15 & 45.86 & 16 \\
\hline 38 & 608 & 53 & 1 & 1124 & 2 & 3.9 & 667 & 3.16 & 59.34 & 40 \\
\hline 39 & 4120 & 460 & 4 & 6902 & 8 & 15 & 4100 & 3.31 & 59.40 & 483 \\
\hline 40 & 4269 & 54 & 7 & 9000 & 13 & 26.65 & 6584 & 3.19 & 69.22 & 142 \\
\hline
\end{tabular}

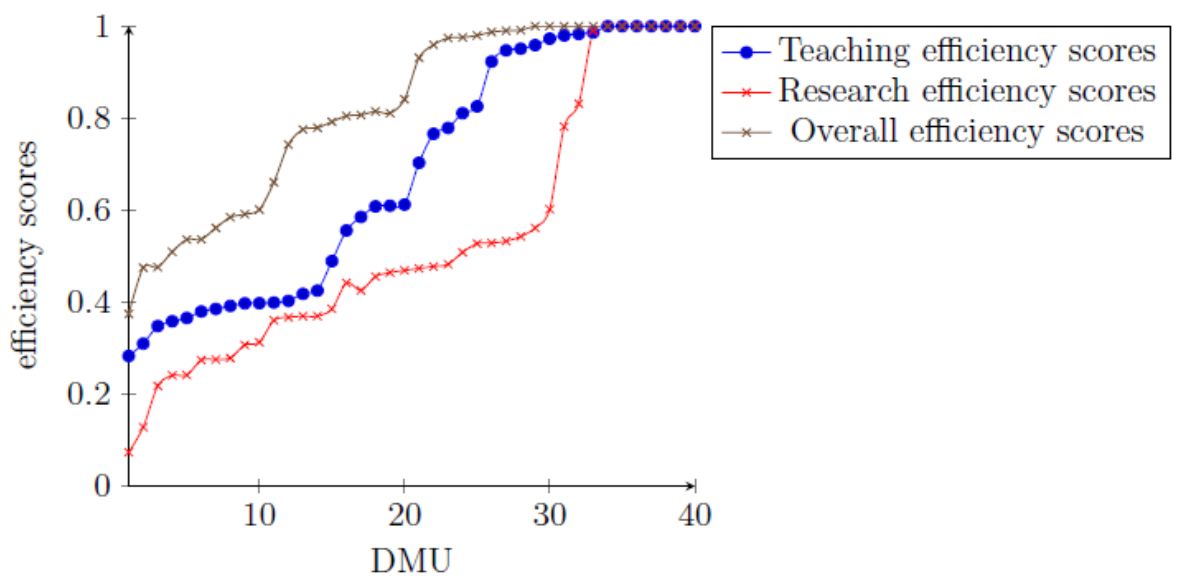

FIGURE 2. Graphical description of efficiency of HEIs 
Comparison between groups of Higher Education Institutions

From the educational managers' perspective, a comparison is a tool to examine the performance of the institutions among themselves. In this study, the institutions can be grouped as public HEIs and private HEIs. Public institutions receive funding directly from the government. On the other hand, private institutions do not receive funding from the government. On average, the teaching efficiency at public institutions $(0.6681)$ is lower than the teaching efficiency at private institutions (0.7131). On the contrary, on the research performance, it is vice versa that the average performance of the public institution in research activity $(0.5371)$ is better than the average performance of private institutions in research activity (0.5229). Hence, private institutions give higher emphasis on teaching activity while public institutions focus on research. Moreover, the overall performance of private institutions is higher than the performance of public institutions (0.8490) vs $(0.8084)$, respectively.

From the obtained results, it implies each group of institutions give much emphasis according to their interest.
In addition, an investigation of why a particular institution has a better performance in specific activity might provide valuable insights to identify the best practices in education and apply them to the low performed institution. According to Abbott and Doucouliagos (2003), a comparison between the HEIs efficiencies enables the educational managers to have a better understanding of how scarce resources can be reallocated to improve the HEIs' productivity. The distribution of efficiency scores of the types of institutions is presented in Figure 3.

From Figure 3, a distribution of efficiency scores of HEIs helps to get a quick visual picture of the performance of private HEIs vs public HEIs without doing any further calculation. For instance, 4 private HEIs were fully efficient due to their efficiency scores of $100 \%$ while 9 private institutions had their efficiency scores ranging from $50 \%$ up to $100 \%$ with the lowest efficiency score of $56.15 \%$. Similarly, 8 public HEIs were fully efficient and the efficiency scores of 27 public institutions had a range of $37.45 \%$ up to $100 \%$ with the lowest efficiency score of $37.45 \%$.

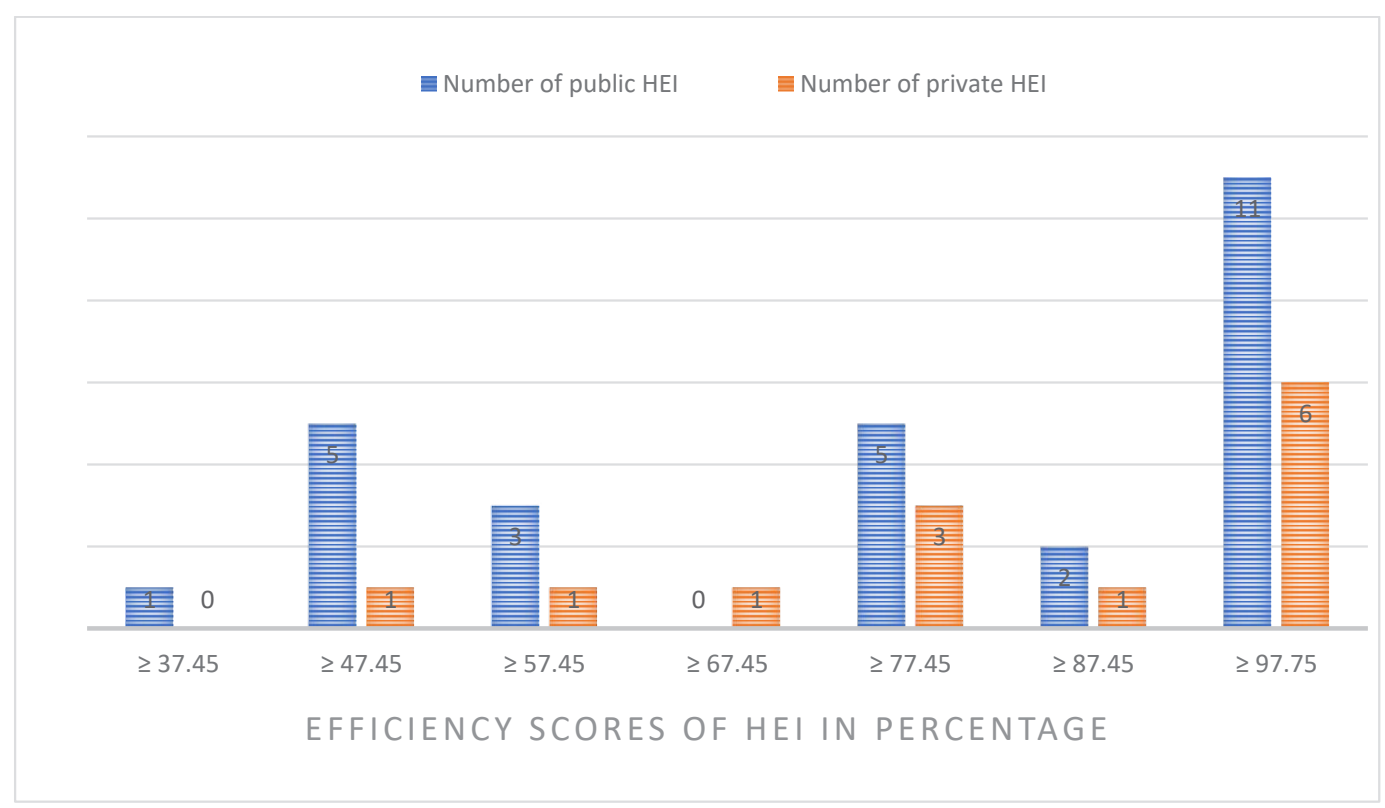

FIGURE 3. Distribution of efficiency scores of HEIs

\section{CONCLUSION}

We measured the teaching efficiency, research efficiency, and overall efficiency of 40 HEIs using a joint DEA model and found the following empirical results: firstly, HEI that efficient in either teaching or research is also efficient in its overall performance. This implies that it is more advantageous for the institutions to adopt both activities instead of adopting a single activity. Moreover, the joint implementation of teaching and research provides an opportunity for institutions to work effectively on both 
activities and then, enhance their performance. Therefore, the joint adoption of teaching and research leads to better performance of HEIs rather than adopting of a single activity. Secondly, teaching is more homogeneous than research productivity among the HEIs. The heterogeneity of research productivity probably comes from facing difficulties in investing high budget and funding low monetary resources on it. Moreover, by comparing public vs private institutions, useful insights were obtained from the grouped HEIs that private institutions focus mainly on teaching activity rather than a public one. On the other hand, public institutions give more emphasis on research productivity than private. Lastly, the efficiency scores of the HEIs could inform the educational decisionmakers and other stockholders to use better ways of resource allocation among the institutions. Moreover, the educational administrates enables to categorize the institutions based on their performance and uses the set of efficient HEIs as a role model to evaluate other institutions' performance. According to Abbott and Doucouliagos (2003) and Avkiran (2011), efficiency analysis does not include in the educational assessment of the institutions that facilitate the failure of efficient allocation of resources among the institutions.

Joint implementation of teaching and research in higher education leads to increase capacity in introducing process innovations like new approaches in the learning process and the faculty members update their knowledge with current information. Moreover, it enables institutions to carry out their activities through an evidence-based approach. Therefore, joint implementation of these activities helps to have positive effects between them and each activity has a marginal return of the other.

\section{ACKNOWLEDGEMENTS}

The first author acknowledges COMSATS University Islamabad and The World Academic of Science (TWAS) for the CIIT-TWAS full-time postgraduate fellowship award (FR: 3240287170). The authors declare that they do not have conflicting financial interests or personal relationships that could have appeared to have influenced the research reported in the paper.

\section{REFERENCES}

Abbott, M. \& Doucouliagos, C. 2003. The efficiency of Australian universities: A data envelopment analysis. Economics of Education Review 22(1): 89-97.

Afonso, A. \& Aubyn, M.S. 2006. Cross-country efficiency of secondary education provision: A semi-parametric analysis with non-discretionary inputs. Economic Modelling 23(3): 476-491.
Agasisti, T. 2014. The efficiency of public spending on education: An empirical comparison of EU countries. European Journal of Education 49(4): 543-557.

Aviles-Sacoto S. 2012. A restricted multiplier DEA model for identifying best practices for attracting students into a Mexican university - case study: School of Business at ITESM, Master's thesis, (ITESM) (Technological and Higher Education Institute of Monterrey, Mexico) (Unpublished).

Avkiran, N.K. 2011. Applications of data envelopment analysis in the service sector. In Handbook on Data Envelopment Analysis. Boston: Springer. pp. 403-443.

Banker, R.D., Charnes, A. \& Cooper, W.W. 1984. Some models for estimating technical and scale inefficiencies in data envelopment analysis. Management Science 30(9): 10781092.

Beasley, J.E. 1995. Determining teaching and research efficiencies. Journal of the Operational Research Society 46(4): 441-452.

Boulton, G. \& Lucas, C. 2011. What are universities for? Chinese Science Bulletin 56(23): 2506-2517.

Bradley, S., Johnes, G. \& Millington, J. 2001. The effect of competition on the efficiency of secondary schools in England. European Journal of Operational Research 135(3): 545-568.

Castano, M.C.N. \& Cabanda, E.C. 2007. Performance evaluation of the efficiency of Philippine Private Higher Educational Institutions: Application of frontier approaches. International Transactions in Operational Research 14(5): 431-444.

Charnes, A. \& Cooper, W.W. 1962. Programming with linear fractional functionals. Naval Research Logistics Quarterly 9(4): 181-186.

Charnes, A., Cooper, W.W. \& Rhodes, E. 1978. Measuring the efficiency of decision making units. European Journal of Operational Research 2(6): 429-444.

Chen, J.K. \& Chen, I.S. 2011. Inno-Qual efficiency of higher education: Empirical testing using data envelopment analysis. Expert Systems with Applications 38(3): 18231834.

Cook, W.D., Tone, K. \& Zhu, J. 2014. Data envelopment analysis: Prior to choosing a model. Omega 44: 1-4.

Dufrechou, P.A. 2016. The efficiency of public education spending in Latin America: A comparison to highincome countries. International Journal of Educational Development 49: 188-203.

Elbanna, S. \& Abdel-Maksoud, A. 2020. Organizational resources and performance: The case of an oil-rich country. Public Performance \& Management Review 43(3): 713-739.

Farrell, M.J. 1957. The measurement of productive efficiency. Journal of the Royal Statistical Society: Series A (General) 120(3): 253-281.

Fromhold-Eisebith, M. \& Werker, C. 2013. Universities' functions in knowledge transfer: A geographical perspective. The Annals of Regional Science 51(3): 621-643.

Gupta, S., Verhoeven, M. \& Tiongson, E.R. 2002. The effectiveness of government spending on education and 
health care in developing and transition economies. European Journal of Political Economy 18(4): 717-737.

Hall, P. 1986. On the number of bootstrap simulations required to construct a confidence interval. The Annals of Statistics 14(4): 1453-1462.

Hanushek, E.A. \& Woessmann, L. 2008. The role of cognitive skills in economic development. Journal of Economic Literature 46(3): 607-668.

Hanushek, E.A. \& Luque, J.A. 2003. Efficiency and equity in schools around the world. Economics of Education Review 22(5): 481-502.

Herbst, M. 2007. Financing public universities. Higher Education Dynamics 18(1): 90-94.

Johnes, J. 2006. Measuring teaching efficiency in higher education: An application of data envelopment analysis to economics graduates from UK Universities 1993. European Journal of Operational Research 174(1): 443-456.

Johnes, J. \& Li, Y.U. 2008. Measuring the research performance of Chinese higher education institutions using data envelopment analysis. China Economic Review 19(4): 679-696.

Joumady, O. \& Ris, C. 2005. Performance in European higher education: A non-parametric production frontier approach. Education Economics 13(2): 189-205.

Kirjavainen, T. \& Loikkanent, H.A. 1998. Efficiency differences of Finnish senior secondary schools: An application of DEA and Tobit analysis. Economics of Education Review 17(4): 377-394.

Kong, W.H. \& Fu, T.T. 2012. Assessing the performance of business colleges in Taiwan using data envelopment analysis and student based value-added performance indicators. Omega 40(5): 541-549.

Lall, V. \& Teyarachakul, S. 2006. Enterprise resource planning (ERP) system selection: A data envelopment analysis (DEA) approach. Journal of Computer Information Systems 47(1): 123-127.

Lang, D.W. \& Zha, Q. 2004. Comparing universities: A case study between Canada and China. Higher Education Policy 17(4): 339-354.

Lee, B.L. \& Worthington, A.C. 2016. A network DEA quantity and quality-orientated production model: An application to Australian university research services. Omega 60: 26-33.

Leithwood, K. \& Menzies, T. 1998. Forms and effects of schoolbased management: A review. Educational Policy 12(3): 325-346.

Liefner, I. 2003. Funding, resource allocation, and performance in higher education systems. Higher Education 46(4): 469-489.

Liu, J.S., Lu, L.Y., Lu, W.M. \& Lin, B.J. 2013. A survey of DEA applications. Omega 41(5): 893-902.

Mancebon, M.J. \& Molinero, C.M. 2000. Performance in primary schools. Journal of the Operational Research Society 51(7): 843-854.

Molinero, C.M. 1996. On the joint determination of efficiencies in a data envelopment analysis context. Journal of the Operational Research Society 47(10): 1273-1279.

Moncayo-Martínez, L.A., Ramírez-Nafarrate, A. \& HernándezBalderrama, M.G. 2020. Evaluation of public HEI on teaching, research, and knowledge dissemination by data envelopment analysis. Socio-Economic Planning Sciences 69: 100-115.

Nazarko, J. \& Saparauskas, J. 2014. Application of DEA method in efficiency evaluation of public higher education institutions. Technological and Economic Development of Economy 20(1): 25-44.

Ramzi, S. \& Ayadi, M. 2016. Assessment of universities efficiency using data envelopment analysis: Weights restrictions and super-efficiency measure. Journal of Applied Management and Investments 5(1): 40-58.

Sagarra, M., Mar-Molinero, C. \& Agasisti, T. 2017. Exploring the efficiency of Mexican universities: Integrating data envelopment analysis and multidimensional scaling. Omega 67: 123-133.

Shimshak, D.G. \& Wagner, J.M. 2012. Efficiency in public higher education systems: A statewide comparison using data envelopment analysis, In Applications of Management Science. Vol. 15, edited by Lawrence, K.D. \& Kleinman, G. Bingley: Emerald Group Publishing Limited. pp. 19-40. https://doi.org/10.1108.

Simar, L. \& Wilson, P.W. 2007. Estimation and inference in two-stage, semi-parametric models of production processes. Journal of Econometrics 136(1): 31-64.

Simar, L. \& Wilson, P.W. 1998. Sensitivity analysis of efficiency scores: How to bootstrap in nonparametric frontier models. Management Science 44(1): 49-61.

Taylor, B. \& Harris, G. 2004. Relative efficiency among South African universities: A data envelopment analysis. Higher Education 47(1): 73-89.

Wai, C.C. \& Seng, E.L.K. 2014. Exploring the effectiveness and efficiency of blended learning tools in a school of business. Procedia-social and Behavioral Sciences 123: 470-476.

Zhou, C. \& Wang, M. 2009. The evaluation research on higher education efficiency with data envelopment analysis (DEA). 2009 International Conference on Management and Service Science. IEEE. pp. 1-7.

Zoghbi, A.C., Rocha, F. \& Mattos, E. 2013. Education production efficiency: Evidence from Brazilian universities. Economic Modelling 31: 94-103.

Michael Gidey Gebru*, Saqlain Raza \& Mansoor Shaukat Khan Department of Mathematics COMSATS University Islamabad

Pakistan

Michael Gidey Gebru

Department of Mathematics

Adigrat University, Adigrat

Ethiopia

*Corresponding author; email: gidey.michael7@gmail.com

Received: 26 November 2020

Accepted: 13 March 2021 